列

\title{
The last reconnection of the Marmara Sea (Turkey) to the World Ocean: A
} paleoceanographic and paleoclimatic perspective

by

${ }^{* 1,2}$ Cecilia M. G. McHugh, ${ }^{1}$ Damayanti Gurung, ${ }^{3}$ Liviu Giosan, ${ }^{2}$ William B. F. Ryan,

${ }^{4}$ Yossi Mart, ${ }^{5}$ Ummuhan Sancar, ${ }^{2}$ Lloyd Burckle, ${ }^{5}$ M. Namik Çagatay

${ }^{1}$ Queens College, The City University of New York, Flushing, NY, USA;

${ }^{2}$ Lamont-Doherty Earth Observatory of Columbia University, Palisades, NY, USA; ${ }^{3}$ Woods Hole Oceanographic Institution, Woods Hole, MA., USA;

${ }^{4}$ Recanati Institute for Marine Studies, University of Haifa, Haifa, Israel;

${ }^{5}$ Istanbul Technical University, Faculty of Mines, Ayazaga, Istanbul, Turkey

*Correspondent author

E-mail address: cmchugh@qc.cuny.edu; cecilia@Ideo.columbia.edu

\section{Abstract}

During the late glacial, marine isotope Stage 2, the Marmara Sea transformed into a brackish lake as global sea level fell below the sill in the Dardanelles Strait. A record of the basin's reconnection to the global ocean is preserved in its sediments permitting the extraction of the paleoceanographic and paleoclimatic history of the region. The goal of this study is to develop a high-resolution record of the lacustrine to marine transition of Marmara Sea in order to 
24 reconstruct regional and global climatic events at a millennial scale. For this purpose, we mapped 25 the paleoshorelines of Marmara Sea along the northern, eastern, and southern shelves at

26 Çekmece, Prince Islands, and Imrali, using data from multibeam bathymetry, high-resolution

27 subbottom profiling (chirp) and ten sediment cores. Detailed sedimentologic, biostratigraphic

28 (foraminifers, mollusk, diatoms), X-ray fluorescence geochemical scanning, and oxygen and

29 carbon stable isotope analyses correlated to a calibrated radiocarbon chronology provided

30 evidence for cold and dry conditions prior to $15 \mathrm{ka} \mathrm{BP}$, warm conditions of the Bolling-Allerod

31 from $\sim 15$ to $13 \mathrm{ka} \mathrm{BP}$, a rapid marine incursion at $12 \mathrm{ka} \mathrm{BP}$, still stand of Marmara Sea and

32 sediment reworking of the paleoshorelines during the Younger Dryas at $\sim 11.5$ to $10.5 \mathrm{ka} \mathrm{BP}$, and

33 development of strong stratification and influx of nutrients as Black Sea waters spilled into

34 Marmara Sea at 9.2 ka BP. Stable environmental conditions developed in Marmara Sea after 6.0

$35 \mathrm{ka}$ BP as sea-level reached its present shoreline and the basin floors filled with sediments 36 achieving their present configuration.

38 Key Words: late Pleistocene-Holocene; Marmara Sea; sea-level; paleoshorelines; Black Sea;

39 Mediterranean Sea

40

41

42

43

44

45

46 


\section{Introduction}

49 Reconnections of marginal basins to the World Ocean after the late glacial eustatic lowstand 50 can help track global sea-level rise due to the amplified sedimentation changes and complete

51 replacement in the fauna and flora that occurs when these basins switch from lacustrine to

52 marine conditions. Intracontinental basins tend to be small and respond to environmental

53 changes rapidly. Therefore such basins have the potential to capture high-resolution regional and

54 global paleoclimatic and paleoceanographic variability in their sedimentary records (Leventer et

55 al., 1982; Thunell and Williams, 1989; Peterson et al., 1991; Behl and Kennett, 1996; Hughen et

56 al., 1996; Sidall et al., 2003; Ortiz et al., 2004; Major et al., 2006).

57 The Marmara Sea is an intracontinental basin $275 \mathrm{~km}$ long and $80 \mathrm{~km}$ wide formed as a 58 result of pull-apart tectonics along the North Anatolia Fault (Fig. 1; Sengör et al., 1985; Görür et 59 al., 1997; Armijo et al., 1999; 2002; 2005; Okay et al., 1999; Le Pichon et al., 2001; Demirbag et

60 al., 2003). The geological evolution of the Marmara Sea began in the Neogene, late Serravallian,

61 Miocene, and possibly as late as the Plio-Pleistocene. Marmara Sea is divided into three major 62 sub-basins, named Tekirdag, Central, and Çinarcik, from west to east, that are $1200 \mathrm{~m}$ deep.

63 Saddles as shallow as 400 - 600 mbsl separate these basins (Fig. 1). The northern shelf of 64 Marmara Sea is narrow $(\sim 15 \mathrm{~km})$. In contrast, the southern shelf is as broad as $50 \mathrm{~km}$. The 65 dimensions of the drainage basins and river discharge are quite different on the northern and 66 southern margins. To the north the drainage basin is $4,438 \mathrm{~km}^{2}$ in extent, and there are only small 67 streams with no significant discharge (Okay and Ergun, 2005). In contrast, the drainage to the 68 southern margin extends over an area of $30,600 \mathrm{~km}^{2}$ and drains several medium-sized rivers with 69 a total sediment delivery of $6.3 \times 10^{6}$ tons/yr (Ergin et al., 1991). 
The Marmara Sea is connected to the Aegean Sea through the Dardanelles Strait (Görür et

71 al., 1997; Çagatay et al., 1999; 2000). Recent studies by Gökasan et al. (2008) showed that the

72 Dardanelles Strait is $74 \mathrm{~km}$ long, 1.3 to $7.5 \mathrm{~km}$ wide with average water depths of $-60 \mathrm{~m}$. During

73 the last glacial when Marmara Lake was isolated from the Mediterranean Sea, water depths

74 along the Dardanelles Strait averaged -85 m (Gökasan et al., 2008). Marmara Sea is connected

75 to the Black Sea through the Bosporus Strait (Gökasan et al., 1997; 2005). The Strait is $31 \mathrm{~km}$

76 long, and its width varies from 0.7 to $3.5 \mathrm{~km}$ (Algan et al., 2001; Gökasan et al., 1997; 2005).

77 Sills located at the southern and northern entrances of the Bosporus Strait are $-35 \mathrm{~m}$ and $-58 \mathrm{~m}$

78 deep, respectively. The basement topography is irregular and characterized by sills of $-120 \mathrm{~m}$ to

79 the south and $-80 \mathrm{~m}$ to $-70 \mathrm{~m}$ towards the north.

80 The oceanography of the Marmara Sea is characterized by the outflow of brackish water

81 from the Black Sea with salinity of $18 \%$ and inflow of saline intermediate and bottom water

$82(38 \%$ ) from the Aegean Sea (Besiktepe et al., 1994). Water and suspended sediments are

83 delivered to Marmara Sea from the Straits of Dardanelles and Bosporus. These straits help

84 maintain the balance between water supply and evaporation. The flux rate of suspended solids

85 for the Dardanelles Strait is $9.0 \times 10^{5}$ tons/yr and for the Bosporus Strait, $14.5 \times 10^{5}$ tons/yr (Ergin

86 et al., 1991). During the last glacial, marine isotope Stage 2, when global sea-level dropped

87 below the $-85 \mathrm{~m}$ Dardanelles Sill, Marmara lost its connection from the global ocean and became

88 a fresh-brackish water lake (Stantley and Blanpied, 1980; Ryan et al., 1997; 2003; Aksu et al.,

89 1999; 2002; Çagatay et al., 1999; 2000). Although the reconnection of Marmara Sea to the

90 Mediterranean Sea has been previously documented, questions remain regarding the level of

91 Marmara Lake at the time of marine incursion and whether the Black Sea outflow to Marmara

92 was vigorous and continuous at the time of the reconnection (Ross and Degens, 1974; Stanley 
93 and Blanpied, 1980; Lane-Serff et al., 1997; Aksu et al., 1999; 2002; Kaminsky et al., 2002;

94 Mudie et al., 2002) or discontinuous (Ryan et al., 1997; 2003; Major et al., 2002; 2006; Myers et

95 al., 2003; Sperling et al., 2003; Giosan et al., 2005). Due to its irregular basement topography

96 and sediment thicknesses, there are questions as to whether the depth of the Bosporus Strait was

97 shallow or deep during the reconnections. Some authors have concentrated on characterizing the

98 stratigraphy, sediment infill, delta formation, and physical oceanography to shed light into this

99 problem (Ergin et al., 1991; Algan et al., 2001; Hiscott et al., 2002; Myers et al., 2003; Sidall et

100 al., 2004; Gökasan et al., 1997; 2005; Eris et al., 2007).

101 This study uses geophysical, sedimentological, biostratigraphic, physical and geochemical

102 data, as well as stable isotopes obtained from foraminifera to document the reconnection of

103 Marmara Lake to the global ocean and to address the following questions. 1) Was the surface of

104 the Marmara Lake below its outlet to the Aegean Sea just prior to the reconnection? If so, was

105 this indicative of regional drought conditions? 2) Was the Marmara Lake isolated from the Black

106 Sea during its reconnection to the global ocean? 3) Was the incursion of marine waters in the

107 brackish-fresh water lake rapid and accompanied by extensive changes in paleo-depositional

108 environments (i.e., the migration of the shoreface and drowning of river beds), faunal (mollusks,

109 foraminifers) and floral (diatom) assemblages? 4) What paleoclimatic and paleoceanographic

110 events can be detected in the lake and marine records and can these events be recognized at

111 millennial-scale variability?

112 The data that forms the basis for this study was collected during geophysical surveys and

113 sediment sampling conducted from the $R / V$ Mediterranean Explorer in the summer of 2005 (Fig.

114 1; Mart et al., 2006) and from the R/V Urania in 2001 (Çagatay et al., 2003; Polonia et al., 2004;

115 Cormier et al., 2006). We mapped the paleoshorelines of Marmara Lake along the northern, 
116 eastern, and southern shelves at Çekmece, Prince Islands, and Imrali, respectively. Multibeam

117 bathymetry, high-resolution subbottom profiling (chirp) and sediment cores were obtained from

118 present water depths of -75 to $-300 \mathrm{~m}$.

\section{Methods}

121 The $R / V$ Mediterranean Explorer geophysical survey was conducted with an Edgetech 122 SB424 chirp reflection profiler navigated by GPS. N-S and E-W track lines were separated at $123 \quad 0.1^{\prime}$ spacing (185 - 150 meters). Each surveyed area was approximately 4 by $6 \mathrm{~km}$ wide. The 124 digital field data were sampled at a 0.125 millisecond interval across a 0.2 second window and 125 recorded in EdgeTech format. The files were converted to segy format for shipboard analysis 126 with the TKS Kingdom Suite ${ }^{\circledR}$ software package. Gravity coring was conducted with a $10 \mathrm{~cm}$ 127 diameter and up to $3 \mathrm{~m}$ long barrel with a $400 \mathrm{~kg}$ core head. The $R / V$ Mediterranean Explorer 128 sediment cores were recovered from the Çekmece and Prince Islands margins. The cores were 129 split, photographed, described and sampled in the ship's laboratory. U-channels were taken from 130 each $1.5 \mathrm{~m}$ core section for bulk X-ray fluorescence (XRF) geochemical scanning conducted 131 every $1 \mathrm{~mm}$ along the sediment surface. Bromine relative content (in counts/second), as

132 measured by the XRF scanner, was used to estimate the presence of marine organic matter in the 133 sediments. Bromine is thought to be preferentially associated to marine rather than freshwater134 derived organic matter (Malcolm and Price, 1984). The calcium carbonate content of the 135 sediments was measured every $5 \mathrm{~cm}$ using a Coulometric carbonate-carbon analyzer. The 136 accuracy of this method was $\pm 0.05 \%$. Carbonate content is expressed as $\mathrm{wt} \% \mathrm{CaCO}_{3}$, assuming 137 that all the carbonate was present as calcite. Cores are archived (one half each) at the Istanbul 138 Technical University and the University of Haifa. 
High-resolution multibeam (ELAC1180 system) and subbottom CHIRP profiling (hull

140 mounted Datasonics) conducted at $50 \mathrm{~m}$ spaced grids, were obtained from the $R / V$ Urania in the

141 summer of 2001 (Çagatay et al., 2003; Polonia et al., 2002; 2004; Cormier et al., 2006). Precise

142 navigation was provided by differential GPS positioning and bathymetric maps are referenced to

143 the WGS84 datum. The physical properties of the cores were measured on board of the $R / V$

144 Urania with a Geotech core logger (Polonia et al., 2002). The studied gravity cores IM03 and

145 IM05 were recovered from the Imrali margin from the $R / V$ Urania. To recover the water and

146 undisturbed underlying sediment, the SW-104 coring system was used.

147 Oxygen isotopes were conducted at the Woods Hole Micropaleontology Mass Spectrometer

148 Facility with a Finnegan MAT253 mass spectrometer from the tests of the benthic marine

149 foraminifer Brizalina spp. A chronology was established from ${ }^{14} \mathrm{C}$ derived from mollusks and

150 foraminifers (Table 1). Radiocarbon dating was conducted at the NOSAMS Facility at Woods

151 Hole, MA. Given the great variability in water masses of the Marmara Sea ages are reported as

152 both calibrated years BP and radiocarbon years BP (Table 1). Calibrated ages were obtained by

153 applying Sinai et al. (2000) reservoir correction. The ages were converted to calendar years with

154 CALIB 5.0 program (Stuvier and Reimer, 1993). All the cores identification, water depth and

155 coordinates are described in Table 2 in the Supplementary Data.

156 All sediment cores were sampled every $5 \mathrm{~cm}$ for foraminiferal and mollusk biostratigraphy,

157 except for Cores IM03 and Core 8 that were sampled every $10 \mathrm{~cm}$ (Gurung et al., 2006). All the

158 samples were wet sieved through a $63 \mu \mathrm{m}$ sieve and the fractions of the sample $>63 \mu \mathrm{m}$ were

159 dried and picked for analyses. Mollusks were identified to genus level using Abbott and Dance

160 (1990) and Vaught et al. (1989) and 22 genera were identified. The dominant taxa that were

161 considered before the marine incursion are fresh-brackish mollusks of Caspian affinity and 
162 characteristic of Neoeuxinian Black Sea sediments Dreissena sp. and Theodoxus sp. (Fedorov,

163 1971; Ross and Degens, 1974). After the marine intrusion the molluskan fauna is indicated by

164 shallow littoral marine species of Mediterranean affinity Gouldia sp., Lucinella sp., Corbula sp.,

165 Cardium sp. (Tables 3-11 in Supplementary Data). Foraminifers, at least 300, were picked from

$16610 \mathrm{~g}$ sub-samples, identified to genus level with a binocular microscope, counted, and

167 standardized by calculating percent abundance within each sample (Tables 12-21 in

168 Supplementary Data). Benthic foraminiferal species were identified and counted for Core IM05,

169 and Mediterranean Explorer Cores 6, and 1 on the southern (Imrali), northern (Çekmece), and

170 Prince Islands margins of Marmara Sea (Taxonomy in Appendix A). These cores were chosen to

171 identify species because of their continuous sedimentation as documented by the

172 lithostratigraphy and radiocarbon chronology. Foraminiferal taxonomy is based on Loeblich and

173 Tappan (1988). Further identification to genera and species level was carried out by using

174 Phleger (1960), Murray (1971; 1986), Haynes (1981), Yanko and Troitskaja (1987), Alavi

175 (1988), Cimmerman and Langer (1991), Sgarella and Moncharmont Zei (1993), Lee et al.

176 (2000), Kaminski et al. (2002), Hayward et al. (2003), and Meric et al. (2004).

177 Samples for diatom studies were taken every $5 \mathrm{~cm}$ in Core IM05 and every $10 \mathrm{~cm}$ for Core

178 IM03, chemically treated with $10 \%$ hydrogen peroxide and $10 \%$ hydrochloric acid to extract the

179 diatoms, and thin sections were prepared without heating the samples. The method used

180 represents a slight modification from Renberg (1990). Two hundred diatom valves were counted

181 from each interval, identified to the genus level using Round et al. (1990) and grouped into:

182 freshwater, brackish, and marine (Table 22 in Supplementary Data). Fresh and brackish water

183 diatoms are better preserved in the sediments because they have thick-walls. In contrast marine

184 diatoms are thinner walled, more susceptible to dissolution and not well preserved. The absence 
185 of all diatoms in the sediments that contain marine foraminiferal and mollusk assemblages is

186 interpreted as the result of dissolution rather than low productivity.

188 Results

189 Southern Shelf at Imrali

190 The Imrali shelf-slope region along the Southern Boundary Fault was surveyed between -80

$191 \mathrm{~m}$ and $-300 \mathrm{~m}$ of water depth (Fig. 2). The goal of the survey was to document neotectonic 192 activity along the Southern Boundary Fault and to map the paleoshorelines. The topography of 193 the surveyed region, has a steep slope (up to $20^{\circ}$ ) that subbottom profile records show was 194 created by normal fault activity and a series of rotational slumps concave to the basin (McHugh 195 et al., 2006; Fig. 2). A transect of cores was obtained extending from present water depths of 196100 to $-300 \mathrm{~m}$. Cores IM05 was recovered from $152 \mathrm{~m}$ of water depth at the base of one of these 197 scarps. After reconstruction of the $30 \mathrm{~m}$ of vertical offset during the Holocene (past 10,000 yrs) 198 due to faulting and slumping processes, Core IM05 was positioned at $-115 \mathrm{~m}$ of present water 199 depth (McHugh et al., 2006; Fig. 3). The reconstruction was based on the identification of the 200 seismic reflector that represents the lacustrine to marine transition from the lithology, 201 biostratigraphy and radiocarbon dating. The vertical offsets were measured from the seismic 202 lines and the seismic reflector reconstructed to its original position. Core IM03 was taken at $203298 \mathrm{~m}$ of water depth, $1 \mathrm{~km}$ away from the fault, and its sediments were not offset by fault 204 activity. Three terraces were delineated from the reconstructed subbottom profiles at $-87 \mathrm{~m},-95$ $205 \mathrm{~m}$, and $-115 \mathrm{~m}$ of water depth (Fig. 3). 
Core IM05 was subdivided into four sedimentary facies based on its texture, flora, and

209 fauna (Fig. 4). Facies 1: lacustrine-barren is composed of laminated silty clays with abundant

210 woody material and rare fragments of Neoeuxinian-Caspian affinity mollusks of Dreissena

211 rostriformis and the gastropod Theodoxus fluviatilis (Fedorov, 1971; Ross and Degens, 1974).

212 Sediments of Facies 1 are older than $15.0 \mathrm{ka}$ BP $\left(13.15{ }^{14} \mathrm{C} \mathrm{ka} \mathrm{BP}\right)$. Facies 2: lacustrine-fertile is

213 composed of silty clays with abundant mollusks dominated by Dreissena sp. banks and also by

214 the gastropod T. fluviatilis. These two assemblages were typical of brackish water environments

215 with salinities of 1-5\%o. The lake sediments of Facies 2 also contain brackish water diatoms

216 Cyclotella spp; Cocconeis spp; Diploneis spp. and Amphora spp and freshwater diatoms

217 Stephanodiscus spp; Fragilaria spp; Eunotia spp; Navicula spp; Cymbella spp; Cystopleura spp.

218 During the lake-fertile stage sedimentation rates were as high as $0.4 \mathrm{~cm} /$ year (Fig. 5). Sediments

219 of Facies 2 were deposited between 15.0 to $12.0 \mathrm{ka} \mathrm{BP}\left(13.15{ }^{14} \mathrm{C}\right.$ ka BP and $11.0{ }^{14} \mathrm{C}$ ka $\mathrm{BP}$;

220 Table 1). Facies 3 represents the marine incursion surface and is composed of a $20 \mathrm{~cm}$-thick

221 gravelly sand bed containing flat pebbles typical of a beach environment. A marine mollusk

222 above the sand bed was dated at $11.8 \mathrm{ka} \mathrm{BP}\left(10.7{ }^{14} \mathrm{C} \mathrm{ka} \mathrm{BP}\right)$. Facies 3 separates lacustrine from

223 marine strata and marks a major transformation in the sediments, flora and fauna. Facies 4 is

224 entirely composed of marine sediments and fauna. The sediments are clayey silts and contain

225 marine mollusks, marine benthic and planktonic foraminiferal assemblages. Marine diatom tests

226 were rarely preserved in the sedimentary record due to their dissolution in the water column.

227 Sediments of Facies 4 were deposited from $11.83 \mathrm{ka} \mathrm{BP}\left(10.7{ }^{14} \mathrm{C} \mathrm{ka} \mathrm{BP}\right)$ to the present.

228 Sedimentation rates for the marine facies were very stable at $0.02 \mathrm{~cm} / \mathrm{yr}$ (Fig. 5). Core IM03 is

229 composed of marine muds and marine fauna and it is $350 \mathrm{~cm}$ long. No diatoms were found in

230 Core IM03. The lower section of Core IM03 is laminated and the sparse occurrence of benthic 
231 and planktonic foraminifers suggests that its base was very close to the lake sediments. Core

232 IM03 was dated at $5.7 \mathrm{ka} \mathrm{BP}\left(5.4{ }^{14} \mathrm{C} \mathrm{ka} \mathrm{BP}\right)$ at $230 \mathrm{~cm}$ and $5.5 \mathrm{ka} \mathrm{BP}\left(5.3{ }^{14} \mathrm{C} \mathrm{ka} \mathrm{BP}\right)$ at $150 \mathrm{~cm}$

233 and correlated to Core IM05 based on the radiocarbon ages (Table 1).

235 Physical Properties

236 The bulk density, p-wave velocity and magnetic susceptibility of the sediments were 237 measured on cores IM05 and IM03. They showed an abrupt change at the contact between the 238 lacustrine and marine facies (Fig. 6). The bulk density measurements increased upwards in the 239 core from $1.9 \mathrm{~g} / \mathrm{cm}^{3}$ in the lacustrine-barren Facies 1 to $2.3 \mathrm{~g} / \mathrm{cm}^{3}$ in the lacustrine-fertile Facies

240 2. These high values of bulk density in the lacustrine facies are indicative of low pore water 241 content. In the upper marine part of the core (Facies 4) bulk densities decrease further to values 242 of $1.55 \mathrm{~g} / \mathrm{cm}^{3}$ that are typical of water-saturated surface sediments. The abrupt contact between 243 the lacustrine and marine facies is also accompanied by a decrease in the P-wave velocity from $2441650 \mathrm{~m} / \mathrm{s}$ to $1550 \mathrm{~m} / \mathrm{s}$. The magnetic susceptibility values also exhibited changes from the 245 lacustrine to the marine facies with highest susceptibility at $25 \mathrm{~cm}$ and $140 \mathrm{~cm}$ below the contact.

\section{Benthic and Planktonic Foraminifers}

248 All shelf-slope cores from the southern Marmara margin at Imrali and northern margin at 249 Prince Islands and Çekmece contain similar benthic foraminiferal assemblages (Fig. 7; Gurung et 250 al., 2006). The record of benthic foraminifers in the outer shelf was appropriate for 251 environmental analyses because benthic foraminifers respond rapidly to changing conditions 252 such as deepening, sediment supply, organic matter, and oxygen concentrations (Sen Gupta et 253 al., 1993; 1996). For this study we classified benthic foraminifers based on Murray (1991, 2006), 
254 Kaiko (1994), Cannariato et al. (1999), Kaminski et al. (2002) and Meric and Algan (2007) into

255 two major subgroups: 1) low oxygen concentrations or suboxic: Brizalina spp., Bulimina spp., 256 and Cassidulina spp., and 2) shallow water, tolerant of a wide range in salinity: Elphidium spp. 257 and Ammonia spp. Some species such as Hyalinea spp. and Globobulimina spp. reflect the 258 development of water stratification and high organic carbon flux in shelf environments and have 259 been used to interpret these environmental conditions (Murray 1991, 2006; Schonfeld, 1997; 260 2001; den Dulk et al., 2000; Evans et al., 2002; Fontanier et al., 2002, 2003).

261 Twenty benthic foraminiferal species were found in Core IM05 that indicate changes of 262 salinity, water depth, deepening and development of stratification in the water column. Benthic 263 foraminiferal assemblages were first established during the initial incursion of marine waters at 264 around $12.0 \mathrm{ka} \mathrm{BP}\left(10.7{ }^{14} \mathrm{C}\right.$ ka BP $)$. From $12 \mathrm{ka}$ BP to $11.0 \mathrm{ka}$ BP Cassidulina carinata and then 265 Brizalina spp. (B. catanensis, B. spathulata) were the first marine foraminifers present in the 266 sedimentary record of IM05. Except for the initial marine incursion in which only two species 267 were dominant Brizalina spp. (B. catanensis, B. spathulata, B. alata, B. striatula) exhibited 268 similar patterns throughout the core and has been grouped by genus. The species Ammonia 269 tepida, E. macellum, and E. articulatum were also present during the initial marine incursion, 270 from $12 \mathrm{ka} \mathrm{BP}$ to $11.0 \mathrm{ka} \mathrm{BP}$, and they indicate that the sediments were deposited in a shallow 271 water environment with a wide range in salinity conditions (Debenay et al., 1998; Murray, 2006; 272 Meric and Algan, 2007; Fig. 7). E. macellum is characteristic of seagrass, marsh assemblages 273 further suggesting nearshore environment (Murray, 1991).

274 The relative abundances of C. carinata. and Brizalina spp. decreased from $11.5 \mathrm{ka}$ BP to 10.0 275 ka BP and benthic foraminiferal species were dominated by Bulimina aculeate. Bulimina spp. (B. 276 aculeate; $B$. costata; $B$. marginata; B. elongata) behaved in a similar patter throughout the rest 
277 of the core and was grouped by genus. Deepening was manifested by the near disappearance of

278 the shallow water species Elphidium spp. and A. tepida and by the appearance of planktonic

279 foraminifers at $\sim 11.0 \mathrm{ka}$ BP. Hyalinea balthica made its first appearance at $\sim 11.0 \mathrm{ka}$ BP. $H$.

280 balthica has been interpreted as an indicator for the onset of stratification in the water column in

281 other shelf settings (Scourse et al., 2002; Evans et al., 2002; Murray 2006). Large increases of

282 specimens of $H$. balthica occurred at $9.1 \mathrm{ka} \mathrm{BP}$ and $\sim 6.0 \mathrm{ka}$ BP and they are interpreted as

283 having been produced by outflow of Black Sea waters, and due to deepening as sea level reached

284 near its present position, respectively. Globobulimina affinis is associated to high organic flux

285 ( $>3.5 \mathrm{~g} \mathrm{C} \mathrm{m}^{-2}$ per year) tolerates dysoxia but can also be found under oxic conditions (Schonfeld,

286 1997, 2001; den Dulk et al., 2000; Fontanier et al., 2002, 2003; Murray 2006). Large increases in

287 the abundance of G. affinis at $\sim 10 \mathrm{ka} \mathrm{BP}, 9.1 \mathrm{ka} \mathrm{BP}$ and $8.0 \mathrm{ka} \mathrm{BP}$ are interpreted as influx of

288 nutrients after the Younger Dryas, and outflow of Black Sea waters. After $\sim 6.0$ ka BP all benthic

289 foraminifers showed little variability except for the appearance of A. beccarii a much more

290 tolerant form of Ammonia spp. (Fig. 7; Thomas et al., 2000). The relative abundances of

291 planktonic foraminifers decreased from $35 \%$ to $15 \%$ after 3.24 ka BP (Fig. 7).

293 Stable Isotopes

294 The oxygen isotope record of cores IM05 and IM03 recovered at -150 and -300 m of water 295 depth, respectively, showed values ranging from $2.2 \%$ o $\delta^{18} \mathrm{O}$ at $\sim 12.0 \mathrm{ka} \mathrm{BP}$ to $1.5 \%$ o $\delta^{18} \mathrm{O}$ at 296 present (Fig. 8a). Both cores showed a trend from heavy to light values that reflect high salinity 297 and colder temperatures during the initial incursion of marine waters. The waters gradually 298 freshened and warmed throughout the Holocene. 
Carbon isotopes ranged from -2.5 to $-0.5 \%$ o $\delta^{13} \mathrm{C}$ showing an overall trend to less depleted

300 values. This could be related to a decrease in the organic matter flux and rates of sedimentation

301 as Marmara Sea deepened and the shoreline approached its present position. The $\delta^{13} \mathrm{C}$ values of

302 IM05 and IM03 can be correlated in the upper meter of both cores from $~ 5.0 \mathrm{ka}$ BP to the

303 present, indicating that environmental conditions remained stable at both locations within the

304 past $5.0 \mathrm{ka}$ (Fig. 8b).

$306 \quad$ Eastern Shelf at Prince Islands

307 The Prince Islands shelf was surveyed from -80 to $-120 \mathrm{~m}$ of water depth (Fig. 9). The 308 subbottom profile records showed a terrace at $-93 \mathrm{~m}$ of water depth, deeper than the $-85 \mathrm{~m}$ lake 309 paleoshoreline, and of comparable depth to the paleoshoreline on the Imrali margin. Four cores 310 were recovered from the shelf-slope boundary Core 7 at $-88 \mathrm{~m}$, Core 5 at $-92 \mathrm{~m}$, Core 6 at $-98 \mathrm{~m}$, 311 and Core 8 at -109 m (Table 1 in Supplementary Data; Fig. 9). The coring strategy was based on 312 the expectation of reaching older strata that may have been truncated by erosion during the lake 313 stage of Marmara for reconstructing the lacustrine to marine transition. The oldest sediments 314 were expected to be at the shallowest depths where sub-aerial exposure of the shelf would have 315 led to more erosion. The youngest sediments were expected to be at the deepest parts of the study 316 area due to sediment progradation of younger strata over old, and to the generally better 317 preservation of deeper strata. Cores 6-8 recovered marine sediments and Core 5 penetrated 318 lacustrine strata (Figs. 10-11; Gurung et al., 2006). When compared to lacustrine values (Fig. 319 12), high Br content of over 200 counts/sec also indicated the presence of marine rather than 320 fresh water-derived organic matter in the cores recovered in this region. Core 5 was dated at 10.7 $321 \mathrm{ka} \mathrm{BP}\left(9.9{ }^{14} \mathrm{C} \mathrm{ka} \mathrm{BP}\right)$ at $70 \mathrm{~cm}$ and $11.5 \mathrm{ka} \mathrm{BP}\left(10.4{ }^{14} \mathrm{C} \mathrm{ka} \mathrm{BP}\right)$ at $80 \mathrm{~cm}$. An age of $12.0 \mathrm{ka} \mathrm{BP}$ 
322 was estimated at $100 \mathrm{~cm}$ (Fig. 10). The base of Core 6 was dated from a marine mollusk at 11.7

323 ka BP $\left(10.6{ }^{14} \mathrm{C}\right.$ ka BP $)$. Core 7 was very short $(60 \mathrm{~cm})$. We attributed this lack of penetration

324 and sediment recovery to the stiffness of the low-water content lacustrine strata. The low water

325 content and high bulk density of the lacustrine substrate at or shallower than the present substrate

326 at the $-87.5 \mathrm{~m}$ isobath was most likely intermittently exposed when the Marmara Lake reached

327 its low stand prior to $12 \mathrm{ka} \mathrm{BP}$.

\section{Sediments, mollusks}

330 All four cores (5-8) were primarily composed of silty clay with sandy mud/muddy sand in

331 the lower $30 \mathrm{~cm}$ (Fig. 10). Only Core 5 contained solely lacustrine mollusks at its base. All other

332 cores contained reworked mollusk shells of both marine and fresh water affinity i.e., Corbula

333 spp. and Dreissena spp., respectively, at the bottom suggestive that the marine-lacustrine

334 transition was close but not recovered. Also present towards the base of the cores were charcoal

335 fragments, medium-grained, very well-sorted, and very well-rounded, black sands interbedded

336 with intervals of very indurated clays. Note that very indurated lithologies were also recovered in

337 the lacustrine facies of Imrali and are present at or immediately above the lacustrine-marine

338 transition suggestive of exposure of the shelf. The calcium carbonate measured in the sediments

339 ranges from 10 to $40 \%$ and it reached its greatest weight percent near or at the marine-lacustrine

340 transition (Fig. 13).

\section{Benthic and Planktonic Foraminifers}

343 Following the submersion of the shelf edges at $\sim 12 \mathrm{ka}$ BP, C. carinata was the first 344 abundant marine benthic foraminifer to appear in the sedimentary succession (Fig. 11). The 
345 occurrence of marsh and shallow water A. tepida and Elphidium spp. (E. crispum, E. 346 articulatum, E. macellum $)$ at $11.75 \mathrm{ka} \mathrm{BP}\left(10.6{ }^{14} \mathrm{C} \mathrm{ka} \mathrm{BP}\right)$ in Core 6 and $11.5 \mathrm{ka} \mathrm{BP}\left(10.5{ }^{14} \mathrm{C} \mathrm{ka}\right.$

$347 \mathrm{BP}$ ) in Core 5, document the initial marine transgression. From 11.75 to $10.0 \mathrm{ka}$ BP (10.6 to 9.3

$348{ }^{14} \mathrm{C}$ ka BP) C. carinata is replaced first by Brizalina spp. (B. catanensis, B. spathulata) and then 349 by Bulimina spp. dominated by B. aculeata (Fig. 11). After 10 ky BP A. tepida and Elphidium 350 spp. disappear as the shelf further submerges. Planktonic foraminifers appear in abundance. A 351 very unusual $50 \mathrm{~cm}$ thick deposit was found from 100 to $150 \mathrm{~cm}$ in Core 6 (Fig. 10). The 352 sediments within this interval consist of homogeneous silty clays and contain fragments of 353 marine mollusks and foraminifers. On the chirp records the deposit appears as a 2 m thick semi354 transparent unit interpreted as a homogenite. Earthquakes have been linked to such deposits in 355 the Marmara Sea. The strong shaking of slope sediments generated by an earthquake and 356 seismically induced turbidity currents lead to the resuspension, dilution, and redeposition of fine357 grained sediment the settles to the sea floor draping the basin and forming homogenous deposits 358 (McHugh et al., 2006). A similar process where sediment was stirred and remained in suspension 359 for several months and produced a homogeneous deposit was documented after the 1997 Cariaco 360 Basin earthquake and the 1994 Sanriku-Oki earthquake (Thunell et al., 1999; Itou et al., 2000). 361 After $6 \mathrm{ka} \mathrm{BP}$ the suboxic C. carinata, Brizalina spp. and Bulimina spp. remain stable in their 362 relative abundances.

\section{Northern Shelf at Cekmece}

365 The northern shelf of Marmara Sea at Çekmece was characterized by occurrences of three 366 terraces located at $-87 \mathrm{~m},-93 \mathrm{~m}$ and $-102 \mathrm{~m}$ of water depth (Fig. 14). Cores 4, 1, 2, and 3 were 367 recovered from $-118 \mathrm{~m},-102 \mathrm{~m},-93.3 \mathrm{~m}$, and $-93 \mathrm{~m}$ respectively. The limited penetration for 
Cores 3 and 4 suggests that they bottom a similar stiff, low-water content lacustrine facies as

369 recovered in the IM05 core (Fig. 14). However, the mollusks Dreissena sp. and Theodoxus sp.

370 reveal that lacustrine sediments were reached and recovered in limited thicknesses in Cores 1 and

371 2. The marine incursion was dated at $11.5 \mathrm{ka} \mathrm{BP}$ some $14 \mathrm{~cm}$ above the top of lacustrine

372 sediments providing a minimum age for the event (Fig. 15). Lacustrine sediments were

373 composed of clayey silts with abundant black stains and charcoal fragments. Low Br content

374 (<200 counts/sec) indicates that organic matter is not of marine origin in these sediments (Fig.

375 12). Unfossiliferous beds of indurated clays separated the lacustrine and marine sediments. The

376 marine sediments in all cores are composed primarily of silty clays and sandy muds interrupted

377 by occasional reworked intervals manifested by the mixed mollusk assemblages (marine,

378 lacustrine) and by the ages that showed old above young (Cores 1 and 3; Fig. 14). The transition

379 from lacustrine to marine sediments is characterized by a high variability in $\mathrm{Br}$ content that may

380 be indicative of a variable marine-freshwater character of the basin, but more likely reflecting

381 reworking and redeposition of sediments in the region (Fig. 12). Calcium carbonate weight

382 percentage is greatest (up to $40 \mathrm{wt} \%$ ) within the lacustrine sediments and close to the lacustrine-

383 marine transition but decreases up core (Fig. 13).

385 Benthic and Planktonic Foraminifers

386 Benthic foraminiferal assemblages showed very similar patterns as those from Imrali and

387 Prince Islands (Fig. 16). A. tepida is present towards the base of the core with a prominent 388 abundance peak at $\sim 11.5 \mathrm{ka} \mathrm{BP}$ in Core $1(-102 \mathrm{~m})$. The abundance of Elphidium spp. decreases 389 up core. Bulimina spp. and Brizalina spp. are dominated by B. aculeata and B. spathulata, 390 respectively. From approximately 11.5 to $9.4 \mathrm{ka} \mathrm{BP,} H$. balthica and G. affinis show peak 
391 abundances similar to those documented in the Imrali margin and interpreted as water

392 stratification and nutrient influx possibly due to the Younger Dryas and Black Sea outflow. The

393 part of the sedimentary record extending from $7.35 \mathrm{ka} \mathrm{BP}\left(6.9^{14} \mathrm{C} \mathrm{ka} \mathrm{BP}\right)$ to the present showed

394 a stable abundance of suboxic foraminifers with Brizalina spp. dominating the assemblages.

397 Discussion

The Marmara Sea has captured in its sediments, fauna and flora, paleoclimatic and 400 paleoceanographic changes for approximately the past $15 \mathrm{ka} \mathrm{BP}\left(13.0{ }^{14} \mathrm{C} \mathrm{ka} \mathrm{BP}\right)$, at thousand401 year scales, demonstrating how marginal basins are sensitive to changing paleoenvironmental 402 conditions. The different proxies used (lithology, benthic and planktonic foraminifers, mollusk 403 assemblages, diatoms, physical and geochemical properties and stable isotopes) permitted to 404 track global sea level as it breached the Dardanelles and Bosporus sills and reached its present 405 position allowing for the Mediterranean, Marmara, and Black Sea waters to establish the present 406 day circulation. The measured data allowed us to reconstruct a sequence of events described 407 below (Fig. 17). The ages are listed as calibrated years for global comparison.

409 Marmara Lacustrine Stage (>15.5 ka BP to $12.0 \mathrm{ka} \mathrm{BP})$

410 The deglaciation of the Eurasia continental ice was initiated at $18.0 \mathrm{ka}$ BP and extended 411 until 15.8 ka BP (Bard et al., 1990; Grosswald 1980; 1998; Denton et al., 1999; Svitoch, 1999; 412 Bahr et al., 2005). The effects of the Eurasia deglaciation can be expanded to the Black-Marmara 413 Sea corridor until 15.5 ka BP through a Caspian-Black Sea connection (Bahr et al., 2005). Once 
414 the initial disintegration of the Eurasian continental ice occurred, the retreating ice was not

415 longer a source of meltwater to the Black Sea and consequently for the Marmara Lake (Bahr et 416 al., 2005; Major et al., 2006). The oldest sediments recovered provide evidence of Marmara Lake

417 isolated from the global ocean. The Lake sediments were laminated, indicative of cyclic 418 sedimentation and oxic conditions (Fig. 4). Rivers were proximal bringing terrigenous sediment 419 and the abundant charcoal suggested that the climate was dry with possible fires (Figs. 4, 15). 420 The lake was nearly barren of fauna containing few Dreissena sp. and Theodoxus sp. of brackish 421 and freshwater affinity, and rare brackish and fresh water diatom flora. The magnetic 422 susceptibility data exhibits the greatest values during this barren lake stage. This signal is 423 interpreted as derived from terrigenous sediments transported by rivers that drained into a 424 proximal paleoshoreline (Fig. 6). Dry and cold climatic conditions and a sparsely vegetated 425 landscape, which facilitated the erosion and transport of sediment by rivers, were documented 426 for the Marmara and Black Sea regions at this time, except for the Black Sea southern coast, 427 based on pollen stratigraphy (Caner and Algan, 2002; Filipova-Marinova et al., 2004; Mudie et 428 al., 2001; 2007). From $15.5 \mathrm{ka}$ BP to $14.5 \mathrm{ka} \mathrm{BP}$ there is evidence for an abundant supply of 429 fresh water from the Black Sea (a lake at this time) into Marmara Lake. The lake paleoshorelines 430 lay at the level of its Dardanelles spillway to the Aegean Sea at $-85 \mathrm{~m}$, but isolated from the 431 world's oceans (Lane-Serff et al., 1997; Çagatay et al., 2000; Algan et al., 2001; Aksu et al., 432 2002; Hiscott et al., 2002; Gökasan et al., 2008; Figs. 1, 17). Oligohaline conditions with 433 salinities of 1-5\%o were present as documented by the Caspian-like mollusk assemblages (Fig. 434 4). Dreissena rostriformis and Theodoxus fluviatilis were abundant. The ${ }^{87} \mathrm{Sr} /{ }^{86} \mathrm{Sr}$ compositions 435 of these mollusks have a Black Sea signature (Major personal communication 2006; Major et al., 436 2006). The Bolling-Allerod interstadial brought warm conditions to Marmara Lake as manifested 
437 by the sediments, fauna, and flora of the lacustrine facies. Brackish and freshwater diatoms and

438 woody material became less abundant just prior to the marine incursion when the magnetic

439 susceptibility is high relative to marine values (Fig. 6).

$441 \quad$ Marine Incursion - 12 ka BP

442 The incursion of Mediterranean waters, at $\sim 12.0 \mathrm{ka} \mathrm{BP}$ was accompanied by the replacement

443 of the fauna and flora, the introduction of marine derived organic matter as manifested by $\mathrm{Br}$

$444 \mathrm{cts} / \mathrm{s}$, and a decrease in grain size and calcium carbonate abundance (Figs. 4-7, 12). All these

445 changes were abrupt as measured by the thickness of the sediment over which the change

446 occurred. This thickness is typically a few centimeters. It indicates that a transitional stage, if

447 present was brief. The abruptness in the cores from both the northern and southern shelves

448 contradicts the calculations of Myers et al. (2003) based on hydraulic theory which predicts a

449 transition as long as $2.7 \mathrm{ka}$.

450 Paleoshorelines have been studied in Marmara Lake and used to reconstruct the geologic

451 and climatic history of the region (Ergin et al., 1997; Çagatay et al. 1999; 2000; 2003). The -85

$452 \mathrm{~m}$ terrace has been documented as the lake paleoshoreline at the level of its Dardanelles spillway

453 with the Mediterranean Sea and the $-65 \mathrm{~m}$ terrace as evidence for the Younger Dryas stillstand.

454 The $-95 \mathrm{~m}$ terrace documented in this study marks an erosional surface that can be traced nearly

455 continuously throughout the Marmara Sea (Imrali, Prince Islands and Çekmece margins). The -

$45695 \mathrm{~m}$ terrace, first documented by Aksu et al., 1999, lies almost $10 \mathrm{~m}$ below the Dardanelles

457 bedrock sill. This raises the possibility that the levels of the lake dropped momentarily below the

458 sill before the Mediterranean waters spilled into Marmara, or that wave action in the lake beveled 459 the lake floor to form a terrace $10 \mathrm{~m}$ below the lake surface. The Bolling Allerod, prior to $12 \mathrm{ka}$ 
$460 \mathrm{BP}$, was warm and hence evaporation rates were perhaps high enough to draw down the lake

461 below its outlet. According to Major et al., (2006), the Black Sea responded similarly, expanding

462 when cool and shrinking when warm.

463 Evaporative conditions of Marmara Lake and early Marmara Sea could explain salinity 464 values of $4 \%$ greater than modern values calculated from alkenone measurements by Sperling et

465 al. (2003). The earliest marine sediments have the heaviest oxygen isotope signal $\left(2.3 \%\right.$ o $\delta^{18} \mathrm{O}$; 466 Fig. 8). An evaporative drawdown of the lake and subaerial exposure of the shelf edge would 467 leave a stiff and low water content substrate sampled at a depth below the Dardanelles spillway.

468 Authigenic carbonate precipitation is a common process in lakes experiencing evaporation.

469 High autigenic carbonate is abundant in the Black Sea terminal lacustrine succession (Bahr et al., 470 2005; Major et al., 2006). In the deeper and permanently submerged regions of the Marmara Sea 471 an authigenic carbonate layer was dated at $\sim 12.5-14.5 \mathrm{ka} \mathrm{BP}\left(11.3-13.0{ }^{14} \mathrm{C} \mathrm{ka} \mathrm{BP}\right.$; Reichel and 472 Halbach, 2007). Gypsum crystals were first reported by Stanley and Blanpied (1987) in the 473 sediments of this age. The shelf muds we measured of the same age contain up to $40 \%$ carbonate 474 (Fig. 13). Further work is needed to distinguish autigenic carbonate from the calcite of mollusk 475 shells.

Younger Dryas $11.5-10.5 \mathrm{ka} \mathrm{BP}$

478 The global transition from glacial to interglacial was interrupted by the Younger Dryas cold 479 interstadial (Mangerud et al., 1974; Fairbanks 1989). Our data indicates that the Younger Dryas 480 occurred in the Marmara Sea soon after the marine incursion. A fresh water outflow from the 481 Black Sea into Marmara Sea could have been active during the Younger Dryas as proposed by 482 Major et al. (2002) but there is uncertainty as to weather it was vigorous (Çagatay et al., 2000; 
Algan et al., 2001; Aksu et al., 2002; Hiscott et al., 2002; Major et al., 2002; Eris et al., 2007), or

484 weak (Myers et al., 2003; Major et al., 2006). There is evidence of scour on the shelf at this time 485 because we occasionally find older shells above younger shells, all in the age range of 11.5 to $48610.5 \mathrm{ka} \mathrm{BP}$. There is evidence that the $-65 \mathrm{~m}$ terrace in the Izmit Gulf was formed during a 487 Younger Dryas (Çagatay et al., 2003; Newman 2003). A still stand of sea level was likely during 488 the Younger Dryas, previously identified as the most arid period of the Last Glacial Age for the 489 Eastern Mediterranean and the near East based on pollen data (Rossignol-Strick, 1995; Filipova490 Marinova et al., 2004; Mudie et al., 2007).

\section{Black Sea and Marmara Sea mixing of waters $9.4-9.2 \mathrm{ka} \mathrm{BP}$}

493 The timing and mode of reconnection between the Mediterranean, Marmara, and Black Sea 494 has been heavily contested. Some studies proposed a non-catastrophic and gradual connection 495 between the Mediterranean-Black Sea corridor (i.e., Aksu et al., 2002; Hiscott et al., 2002; 2006) 496 while others proposed an abrupt and rapid process (i.e., Ryan et al., 1997, 2003; Major et al., 497 2002, 2006; Myers et al., 2003; Sidall et al., 2004; Giosan et al., 2005). The detailed analyses of 498 benthic and planktonic foraminiferal assemblages from Marmara Sea shelves have provided 499 additional insights into how the Black Sea connection occurred. It is well established that 500 modern and ancient continental shelf waters undergo changes from oxic to anoxic conditions due 501 to seasonal fluctuations in temperature and salinity, and as a result of longer-term climatic 502 variability (Tyson and Pearson, 1991). Due to their rapid response, benthic foraminifers can 503 document these ecological changes (Tyson and Pearson, 1991; Sen Gupta et al., 1993; 1996; 504 Kaiho, 1994; Kaminski et al., 2002). Global sea level curves show that from 9.0 to 6.6 ka BP 505 sea-level was -50 to $-15 \mathrm{~m}$ below present (Fairbanks, 1989). This means that the shelf edges were 
506 sufficiently submerged to be able to experience variations in ventilation (Figs. 7, 11, 16).

507 Increases in the occurrence of benthic foraminifers $H$. balthica and G. affinis were recorded as 508 pulses in which their abundance increased from 0 to $30 \%$ (Figs. 7, 16). We interpret these pulses

509 beginning at $9.2 \mathrm{ka} \mathrm{BP}$ as a manifestation of water stratification and high nutrients due to Black

510 Sea outflow and the establishment of a two-layer circulation (Schonfeld, 1997, 2001; Dulk et al.,

511 2000; Evans et al., 2002; Fontanier et al., 2002, 2003; Murray 2006; Major et al., 2006). Later

512 pulses in the abundance of $H$. balthica and G. affinis at $\sim 7.6$ and $6.6 \mathrm{ka}$ BP can be explained as

513 changes in organic matter flux that influenced biotic competition with resulting dominance of

514 one fauna over another (Fig. 7).

$516 \quad$ Sea-level reaching the present shoreline - $6 \mathrm{ka} \mathrm{BP}$

517 The stable environmental conditions that developed as sea level reached close to its present 518 position at $6.0 \mathrm{ka} \mathrm{BP}$ were manifested by the lack of change in the abundance of both benthic 519 and planktonic foraminiferal assemblages, the oxygen and carbon isotope records, and the 520 physical properties of the sediments (Figs. 6-8, 11, 16). A two layer circulation was well 521 established by this time with Brizalina spp. dominating the low oxygen concentration forms. 522 There were no major changes in water stratification and flux of organic mater as manifested by 523 the lack of variability in $H$. balthica and $G$. affinis. Only the highly adaptable A. beccarii 524 appears during this time. This species is known to be an opportunistic in other settings (Thomas 525 et al., 2000). Sedimentation continued in the Marmara Sea at a steady rate of $0.02 \mathrm{~cm} /$ year (Fig. 526 5). A slight decrease in the abundance of planktonic foraminiferal assemblages was observed at 527 the Imrali, Çekmece, and Prince Islands shelves (Figs. 7, 11, 16). The decrease can be linked to a 528 slight increase in the magnetic susceptibility of the sediments in Imrali, which may represent an 
529 increase in magnetic minerals due to terrigenous transport (Figs. 6). Increased sediment supply

530 due to deforestation in the Bronze Age is a possible explanation for the decrease in the biogenic

531 proportion of the sediment (Eris et al., 2007).

\section{Conclusions}

The Marmara Sea is a small intracontinental basin that recorded in its sediments fluctuations

536 in climate and water exchange between the Mediterranean and Black Seas demonstrating that

537 such settings can serve as high-resolution repositories of environmental change. Our cores

538 captured the pre-12 ka BP lacustrine lowstand, the onset of the marine incursion and the

539 subsequent Holocene transgression. The Younger Dryas cold interstadial left a faunal signal and

540 evidence of scouring and sediment reworking. The sediments and fauna record the Black Sea

541 outflow beginning at $9.2 \mathrm{ka}$ BP and the subsequent water column stratification as Marmara Sea

542 established its two-layer circulation.

\section{Acknowledgements}

546 We are grateful to Andreas Weill and Eco-Ocean Association of Herzlyia, Israel for making 547 the $R / V$ Mediterranean Explorer survey possible. We also thank the Captain and crew of the $R / V$ 548 Mediterranean Explorer and $R / V$ Urania for their expertise in the collection of the data. We are 549 grateful to the Scientific Party of the $R / V$ Urania and to Drs. Vachtman, Eris, Ulug and 550 Sarikavak for their help during the expeditions. We thank Corinne Hartin and Dr. Karen Kohfeld 551 for their help with analyses at Queens College. We thank Dr. Mustapha Ergin and an anonymous 
552 reviewer for their comments that helped to improve the manuscript. Support for the analyses was

553 from NSF-OCE-0222139; OCE-9807266 and PSC-CUNY 69138-00 38. This is a Lamont-

554 Doherty Earth Observatory publication number \#\#\#.

556 Appendix A

557

558

The key species are listed in alphabetical order. The identification of the benthic 559 foraminifera are carried out on the studies by Murray (1971), Yanko and Troitskaja (1987), Alavi

560 (1988), Loeblich and Tappan (1988), Cimerman and Langer (1991), Sgarrella and Moncharmont 561 Zei (1993), Kaminski et al (2002), Hayward et al. (2003), and Meric et al. (2004).

\section{Adelosina cliarensis (Heron-Allen \& Earland, 1930)}

566 figs. 1-4)

1930 Quinueloculina cliarenesis Heron-Allen \& Earland (p. 58, pl. 3, figs. 26, 31)

\section{Ammonia compacta (Hofker, 1969)}

1969 Streblus compactus Hofker (p. 99, figs. 242-243)

570

1987 Ammonia compacta (Hofker), Yanko and Troitskaja (p. 44, pl. 11, figs. 1-10)

2002 Ammonia compacta (Hofker), Kaminski et al (pl. 5, fig. 8)

572

Ammonia beccari (Linné, 1758)

573

1758 Nautilus beccarii Linné, (p. 710, pl. 1, fig. 1a-c)

574

1971 Ammonia beccari (Linné) Murray (p. 151, pl. 62, figs. 1-7)

Ammonia tepida (Cushman, 1926) 
1926 Rotalia beccarii (Linné) var. tepida Cushman (1926, p. 79, pl. 1)

576

577

578

579

580

581

582

583

584

585

586

1991 Ammonia tepida (Cushman) Cimerman and Langer (p. 76, pl. 87, figs. 10-12)

2003 Ammonia tepida (Cushman) Hayward et al (pl. 1, figs. 1-3)

Asterigerinata mamilla (Williamson, 1858)

1858 Rosalina mamilla Williamson (p. 54, pl. 4, figs. 109-111)

1971 Asterigerinata mamilla (Williamson) Murray (1971, p. 141, pl. 59, figs. 1-9)

1991 Asterigerinata mamilla (Williamson) Cimerman and Langer (p. 73, pl. 82, figs. 1-4)

Bigenerina nodosaria d'Orbigny, 1826

1826 Bigenerina nodosaria d'Orbigny (p. 261, pl. 11, figs. 9-12)

1993 Bigenerina nodosaria d'Orbigny Sgarrella and Moncharmont Zei (p. 164, pl. 4, fig.

12)

Brizalina alata (Seguenza, 1862)

1862 Vulvulina alata Seguenza (p. 115, pl. 2, fig. 5).

1991 Brizalina alata (Seguenza), Cimerman and Langer (p. 59, pl. 61, figs. 12-14)

Brizalina catanensis (Segunenza, 1862)

1862 Bolivina catanensis Segunenza, (p.113, 125, pl.2, fig.3)

1993 Bolivina catanensis Segunenza, Sgarrella and Moncharmont Zei (p. 208, pl. 14, figs. 45)

2002 Brizalina catanensis (Segunenza), Kaminski et al (pl. 2, fig. 11)

Brizalina spathulata (Williamson, 1858)

1858 Textularia variabilis var. spathulata Williamson (p. 76, pl. 6, figs. 164-165).

1991 Brizalina spathulata (Williamson), Cimerman and Langer (p. 60, pl. 62, figs. 3-5)

Brizalina striatula (Cushman 1922) 
1922 Bolivina striatula Cushman (p. 27, pl. 3, fig. 10)

1991 Brizalina striatula (Cushman) Cimerman and Langer (p. 60, pl. 62, figs. 6-9)

600 2002 Brizalina striatula (Cushman) Kaminski et al. (pl. 2, fig. 10)

\section{Bulimina aculeate d'Orbigny, 1826}

602

1826 Bulimina aculeata d'Orbigny (p. 269)

1993 Bulimina aculeata d'Orbigny, Sgarrella \& Moncharmont Zei (p. 211, pl. 15, fig. 1)

\section{Bulimina costata d'Orbigny, 1852}

1852 Bulimina costata d'Orbigny (p. 194)

606

1993 Bulimina costata d'Orbigny Sgarrella and Moncharmont Zei (p. 211, pl. 15, fig. 3)

\section{Bulimina elongata d'Orbigny, 1846}

1846 Bulimina elongata d'Orbigny (p. 187, pl. 11, figs. 19-20)

609

1993 Bulimina elongata d'Orbigny Sgarrella and Moncharmont Zei (p. 211, pl. 15, fig. 10-

610

11)

2002 Bulimina elongate d'Orbigny, Kaminiski et al. (pl. 3, fig. 4)

Bulimina marginata d'Orbigny, 1826

613

1826 Bulimina marginata, d'Orbigny (p. 269, pl. 12, figs. 10-12).

614 1991 Bulimina marginata d'Orbigny, Cimerman and Langer (1991, p. 62, pl. 64, figs. 9-11) 1993 Bulimina marginata d'Orbigny, Sgarrella and Moncharmont Zei (p. 212, pl. 15, figs. 616 5-7)

\section{Cassidulina carinata Silvestri, 1896}

618 1896 Cassidulina laevigata d'Orbigny var. carinata Silvestri, (p. 104, pl. 2, figs. 10a-c) 1971 Cassidulina carinata Silvestri, Murray (p. 187, pl. 78, figs. 1-5) 
1993 Cassidulina carinata Silvestri, Sgarrella and Moncharmont Zei (p. 236, pl. 23, figs. 8-

$6219)$

625238, pl. 24, fig. 11)

\section{Discorbinella bertheloti (d'Orbigny, 1839)} 1839 Rosalina bertheloti d'Orbigny (p. 135, pl. 1, figs. 28-30) 1993 Discorbinella bertheloti (d'Orbigny), Sgarrella and Moncharmont Zei (p. 216, pl. 16, figs. 11-12) 2002 Discorbinella bertheloti (d'Orbigny, 1839), Kaminiski et al. (pl. 5, figs. 1-2) Elphidium aculeatum (d'Orbigny, 1846) 1846 Polystomella aculeate d'Orbigny (p. 131, pl. 6, figs. 27-28) 1991 Elphidium aculeatum (d'Orbigny) Cimerman and Langer (p. 77, pl. 89, figs. 1-4) Elphidium complanatum (d'Orbigny, 1839)

637 figs .9-10)

$$
\text { Elphidium crispum (Linné, 1758) }
$$

6391758 Nautilus crispus, Linné (p. 709, pl. 1, fig. 2d-f)

6401971 Elphidium crispum (Linné), Murray (p. 155, pl. 64, figs. 1-6) 1991 Elphidium crispum (Linné), Cimerman and Langer (p. 77, pl. 90, figs. 1-6) 
1798 Nautilus macellus var. beta Fichtel \& Moll (p .66, pl. 10, figs. e-g, h-k)

1991 Elphidium macellum (Fichtel \& Moll) Cimerman and Langer (p. 78, pl. 89, fig. 9) 2002 Elphidium macellum (Fichtel and Moll), Kaminski et al. (pl. 5, fig. 11)

\section{Favulina hexagona (Williamson, 1848)}

1848 Entosolenia squamosa (Montagu) var. hexagona-Williamson (p. 20, pl. 2, fig. 23) 1991 Favulina hexagona (Montagu) Cimerman and Langer (p. 55, pl. 58, figs. 8-9)

\section{Fursenkonia acuta (d'Orbigny, 1846)}

1846 Polymorphina acuta d'Orbigny (p. 234, pl. 13, figs. 4-5; pl. 14, figs. 5-7) 1993 Fursenkoina acuta (d'Orbigny) Sgarrella and Moncharmont Zei (p. 235, pl. 23, fig. 7) 2002 Fursenkonia acuta (d'Orbigny), Kaminski et al. (pl. 3, figs. 11-12)

\section{Globobulimina affinis (d'Orbigny, 1839)}

1839 Bulimina affinis d'Orbigny (p. 105, pl. 2, figs. 25-26) 2002 Globobulimina affinis (d'Orbigny), Kaminski et al. (pl. 3, fig. 8)

\section{Globocassidulina subglobosa (Brady, 1884)} 1884 Cassidulina subglobosa Brady (p. 430, pl. 54, fig. 17 a-c) 1971 Globocassidulina subglobosa (Brady), Murray (p. 191, pl. 80, figs. 1-4) 1991 Globocassidulina subglobosa (Brady), Cimerman and Langer (p. 61, pl. 63, figs. 4-6) 1798 Nautilus depressulus Walker and Jacob (p. 641, fig. 33) 1971 Nonion depressulum (Walker and Jacob) Murray (p. 195, pl. 82, figs. 1-8) 2002 Haynesina depressula (Walker and Jacob) Kaminski et al. (pl. 4, figs. 4-5) 
Hyalinea balthica (Schröter, 1783)

6671783 Nautilus balthicus Schroter (p. 20, pl. 1, fig. 2)

6681993 Hyalinea baltica (Schroter) Sgarrella and Moncharmont Zei (p. 234, pl. 22, fig. 12)

6692002 Hyalinea baltica (Schroeter) Kaminski et al. (pl. 3, fig. 13)

6702004 Hyalinea balthica (Schroter) Meric et al. (pl. 27, fig. 3)

$671 \quad$ Lagena striata (d'Orbigny, 1839)

672

1839 Oolina striata d'Orbigny (p. 21, pl. 5, fig. 12)

673

1991 Lagena striata (d’Orbigny) Cimerman \& Langer (p. 53, pl. 55, figs. 6-7)

674

1993 Lagena striata (d'Orbigny) Sgarrella and Moncharmont Zei (p.198, pl.12, figs. 2-3)

675

Lobatula lobatula (Walker and Jacob, 1798)

676

1798 Nautilus lobatulus, Walker and Jacob (p. 642, pl. 14, fig. 36)

677

1988 Lobatula lobatula (Walker and Jacob), Loeblich and Tappan (p. 168, pl. 637, figs. 10-

678 13)

679

1991 Lobatula lobatula (Walker and Jacob), Cimerman and Langer (p. 71, pl. 75, figs. 1-4)

680

Nonionella opima Cushman, 1947

681

1947 Nonionella opima, Cushman (p. 90, pl. 20, figs. 1-3)

682

1991 Nonionella opima Cushman, Cimerman and Langer (p. 74, pl. 84, figs. 1-3)

683

Nonionella turgida (Williamson, 1858)

684

1858 Rotalina turgida, Williamson (p. 50, pl. 4, figs. 95-97)

685

1971 Nonionella turgida (Williamson), Murray (p. 193, pl. 81, figs. 1-5)

686

1991 Nonionella turgida (Williamson), Cimerman and Langer (p. 74, pl. 84, figs. 6-8)

687

Planorbulina mediterranensis d'Orbigny 1826

688

1826 Planorbulina mediterranensis d'Orbigny (p. 280, no. 2) 
1988 Planorbulina mediterranensis d'Orbigny, Loeblich and Tappan (p. 170, pl. 645, figs.

$690 \quad 1-2)$

1991 Planorbulina mediterranensis d'Orbigny, Cimerman and Langer (p. 71-72, pl. 78, 692 figs. 1-8)

\section{Quinqueloculina seminulum (Linné, 1758)}

1758 Serpula seminulum Linné (p. 786, pl. 2, fig. 1-a-c)

1971 Quinqueloculina seminulum (Linné) Murray (p. 64, pl. 24, figs. 1-6) 1991 Quinqueloculina seminula (Linné), Cimerman and Langer (p. 38, pl. 34, figs. 9-12) Rectuvigerina phlegeri Le Calvez, 1959

1988 Rectuvigerina phlegeri Le Calvez, Alavi (pl. 1, fig. 4)

1993 Rectuvigerina phlegeri Le Calvez, Sgarrella and Moncharmont Zei (p. 215, pl. 16, figs.

\section{Spiroloculina excavata d'Orbigny, 1846}

1846 Spiroloculina excavata d'Orbigny, (p. 271, pl. 16, figs. 19-21) 2002 Spiroloculina excavata d'Orbigny, Kaminski et al. (pl. 1, fig. 11)

\section{Textularia bocki Höglund, 1947}

1947 Höglund (p. 171, pl. 12, figs. 5-6)

1991 Textularia bocki Höglund, Cimerman and Langer (p. 21, pl. 10, figs. 3-6)

709 2002 Textularia bocki Höglund, Kaminski et al. (pl. 1, figs. 1-2) 
1993 Uvigerina mediterranea Hofker, Sgarrella and Moncharmont Zei (p. 214, pl. 16, fig. 1-

714 2)

$715 \quad$ Valvulineria bradyana (Fornasini, 1900)

7161900 Discorbina bradyana Fornasini (p. 393, fig. 43)

1991 Valvulineria bradyana (Fornasini) Cimerman and Langer (p. 64, pl. 67, figs. 8-10)

1993 Valvulineria bradyana (Fornasini), Sgarrella and Moncharmont Zei (p. 220, pl. 18, 719 figs. 1-2)

720 


\section{REFERENCES:}

722 Abbott, R.T., Dance, S.P. 1990. Compendium of seashells: a color guide to more than 4,200 of 723 the world's marine shells. $4^{\text {th }}$ Edition. American Malacologists, Melbourne, Florida, USA, $724 \quad 411 \mathrm{pp}$

725 Aksu, A.E., Hiscott, R.N. and Yasar, D. 1999. Oscillating Quaternary water levels of the Marmara Sea and vigorous outflow into the Aegean Sea from the Marmara Sea-Black Sea

Aksu, A.E., Hiscott, R.N., Kaminski, M.A., Mudie, P.J., Gillespie, H., Abrajano, T., Yasar, D. 2002. Last glacial-Holocene paleoceanography of the Black Sea and Marmara Sea: stable isotopic, foraminiferal and coccolith evidence. Marine Geology 3160, 1-31.

Alavi, S.N. 1988. Late Holocene Deep-Sea Benthic Foraminifera from the Sea of Marmara. Marine Micropaleontology 13, 213-237.

Algan, O., Çagatay, N., Tchepalyga, A., Ongan, D., Eastone, C., Gokasan, E. 2001. Stratigraphy of the sediment infill in Bosphorus Strait: water exchange between the Black and Mediterranean Seas during the last glacial Holocene. Geo-Marine Letters 20, 209-218.

Armijo R., Meyer B., Hubert A., Barka A. A. 1999. Westward propagation of the north Anatolian fault into the northern Aegean: Timing and kinematics. Geology 27 267-270.

Armijo R., Meyer B., Navarro S., King G. C. P., Barka A. A. 2002. Asymmetric slip partitioning in the Sea of Marmara pull-apart: a clue to propagation processes of the North Anatolian

741 Armijo, R., Pondard, N., Meyer, B., Uçarkus, G., Mercier de Lepinay, B., Malavieille, J., 742 Dominguez, S., Gustcher, M.-A., Schmidt, S., Beck, C., Çagatay, M. N., Çakir, Z., Imren, 
C., Eris, K., Natalin, B., Özalaybey, S., Tolun, L. G., Lefèvre, I., Seeber, L., Gasperini, L.,

Rangin, C., Emre, Ö., Sarikavak, K. 2005. Submarine fault scarps in the Sea of Marmara pull-apart (North Anatolian Fault): Implications for seismic hazard in Istanbul, Geochemistry, Geophysics, Geosystems 6, Q06009.

747 Bahr, A., Lamy. F., Arz, H., Kuhlmann, H., Wefer, G. 2005. Late glacial to Holocene climate and sedimentation history in the NW Black Sea. Marine Geology 214, 309-322.

Bard, E. Hamelin, B., Fairbanks, R.G., Zindler, A. 1990. Calibration of the 14C timescale over the past 30,000 years using mass spectrometric U-Th ages from Barbados corals. Nature

Behl, R.J., Kennett, J.P. 1996. Brief interstadial events in the Santa Barbara Basin, NE Pacific, during the past 60kar. Nature 379, 243-246.

754 Besiktepe, S.T., Sur, H.I., Ozsoy, E., Latif, M.A., Orguz, T., Unluata, A. 1994. The circulation and hydrography of the Marmara Sea. Progress in Oceanography 34, 285-334. 1999. A mid-late Holocene sapropelic sediment unit from the southern Marmara sea shelf and its paleoceanographic significance. Quaternary Science Reviews 18, 531-540.

762 Çagatay, M.N., Görür, N., Polonia, A., Demirbag, E., Sakinç, M., Cormier, M.-H., Capotondi, 763 L., McHugh, C.M.G., Emre, Ö., Eris, K. 2003. Sea-level changes and depositional 764 environments in the Izmit Gulf, eastern Marmara Sea, during the late glacial-Holocene 765 period. Marine Geology 202,159-173. 
766 Caner, H., Algan, O. 2002. Palynology of sapropelic layers from the Marmara Sea. Marine 767 Geology 190, 35-46.

768 Cannariato, K.G., Kennett, J.P., Behl, R.J. 1999. Biotic response to late Quaternary rapid climate 769 switches in Santa Barbara Basin: Ecological and evolutionary implications. Geology 27, $770 \quad 63-66$.

771 Cimmerman, F., Langer, M. R., 1991. Mediterranean Foraminifera. Slovenska Akdemija 772 Znanosti in Umetnosti. Classis IV: Historia Naturales dela Opera 30, Ljubljana. 119pp, 93 773 pls.

774 Cormier, M.-H., Seeber, L., McHugh, C.M.G., Polonia, A., Çagatay, M.N., Emre, O., Gasperini, 775 L., Görür, N., Bortoluzzi, G., Bonatti, E., Ryan, W.B.F., Newman, K. 2006. The North 776 Anatolian fault in the Gulf of Izmit (Turkey): Rapid vertical motion in response to minor 777 bends of a non-vertical continental transform. Journal of Geophysical Research 111, 778 doi:1029/2005JB003633, B04102.

779 Demirbag, E., Rangin, C., LePichon, X., Sengör, A.M.C. 2003. Investigation of the tectonics of 780 the Main Marmara Fault by means of deep-towed seismic data. Tectonophysics 361, 1-19.

781 Denton, G.H., Heusser, C.J., Lowell, T.V., Moreno, P.I., Anderson, B.G., Heusser, L.E., 782 Schluchter, C., Marchant, D.R. 1999. Interhemispheric linkage of paleoclimate during the 783 last glaciation. Geografiska Annaler 81, 107-153.

784 Debenay, J. -P., Benetau, E., Zhang, J., Stouff, V., Geslin, E., Redois, F., Fernandez-Gonzalez, M. 785 1998. Ammonia beccarii and Ammonia tepida (Foraminifera); morphofunctional arguments 786 for their distinction. Marine Micropaleontology 34 (3, 235-244.

787 Dulk, M. den, Reichart, G.J., Heyst, S. van, Zwaan, G.J. van der, 2000. Benthic foraminifera as 788 proxies of organic matter flux and bottom water oxygenation? A case history from the 789 northern Arabian Sea. Palaeogeography, Palaeoclimatology, Palaeoecology 161, 337-359. 
Ergin, M., Bodur, M.N., Ediger, V., 1991. Distribution of surficial shelf sediments in the northeastern and southwestern parts of the Sea of Marmara: Strait and canyon regimes of the Dardanelles and Bosporus. Marine Geology 96, 313-340.

Ergin, M. Nizamettin, K., Baki, V., Ozden, I., Levent, K., 1997. Sea-level changes and related depositional environments on the southern Marmara Shelf. Marine Geology 140, 391.403.

Eris, K.K., Ryan, W.B.F., Çagatay, M.N., Sancar, U., Lercolais, G., Menot, G., Bard, E., 2007. The timing and evolution of the post-glacial transgression across the Sea of Marmara shelf south of Istanbul. Marine Geology 243, 57-76.

Evans, J.R., Austin, W.E.N., Brew, D.S., Wilkinson, I.P., Kennedy, H.A., 2002. Holocene shelf sea evolution offshore northeast England. Marine Geology, 191, 147-164.

Fairbanks, R.G., 1989. A 17,000-year glacio-eustatic sea level record: influence of glacial melting rates on the Younger Dryas event and deep-ocean circulation. Nature 342, 637-

Fedorov, P.V. 1971. Postglacial transgression of the Black Sea. International Geology Review 642. $14,160-164$.

Filipova-Marinova, M. Chirstova, R., Bozilova, E. 2004. Paleoecological conditions in the Bulgarian Black Sea area during the Quaternary. Journal of Environmental Micropaleontology, Microbiology and Meiobenthology 1, 135-154.

811 Fontanier, C., Jorissen, F.J., Chaillou, G. et al., 2003. Seasonal and interannual variability of 812 benthic foraminiferal faunas at 550m depth in the Bay of Biscay. Deep-Sea Research I, 50, 457-494. 
814 Giosan, L. Mart, Y., McHugh, C.M., Vachtman, D., Çagatay, N.M., Kadir, E.K., Ryan, W.B. 815 2005. Megafloods in Marginal Basins: New Data from the Black Sea. EOS Trans. AGU 86 816 (52): PP32A-03.

817 Gokasan, E., E. Demirbag, F.Y. Oktay, B. Ecevitoglu, M. Simsek, and H. Yüce. 1997. On the 818 origin of the Bosphorus. Marine Geology 140, 183-199.

819 Gökasan E., Algan, O., Tur, H., Meriç, E., Türker, A., Simsek, M. 2005. Delta formation at the 820 southern entrance of Istanbul Strait (Marmara sea, Turkey): a new interpretation based on 821 high-resolution seismic stratigraphy. Geo-Marine Letters 25, 370-377.

822 Gökasan E., Ergin, M. Ozyalvac, M., Ibrahim Sur, H., Tur, H., Görum, T., Ustaömer, T. Gul 823 Batuk, F., Alp. H., Birkan, H., Turker, A., Gezgin, E., Ozturan, M. 2008. Factors 824 controlling the morphological evolution of the Canakkale Strait (Dardanelles, Turkey). 825 Geo-Mar Letters 28, 107-129.

Görür, N., M.N. Çagatay, M. Sakinç, M. Sümengen, K. Sentürk, C. Yaltirak, and A. Tchapalyga. 1997. Origin of the Sea of Marmara as deduced from Neogene to Quaternary Paleogeographic evolution of its frame. International Geology Review 39, 342-352.

829 Grosswald, M.G. 1980. Late Weichselian ice sheet of Northern Europe. Quaternary Research 13, 830 $1-32$.

831 Grosswald, M.G. 1998. Late-Weichselian ice sheets in Arctic and Pacific Siberia. Quaternary 832 International 45-46, 3-18.

833 Gurung, D., McHugh, C.M., Ryan, W.B., Giosan, L., Mart, Y., Çagatai, N. 2006. Late 834 Pleistocene-Holocene climate change inferred from fossil fauna in the Marmara Sea, 835 Turkey. 2006. EOS Trans. AGU 87 (52), PP23B-1748.

836 Haynes, J. R. 1981. Foraminifera. John Wiley \& Sons, New York 433pp. 
837 Hayward, B., Buzas, M.A., Buzas-Stephens, P., Holzman, M., 2003. The lost types of Rotalia 838 Beccarii var tepida Cushman 1926. J. Foraminifer. Res. 33, 352-354.

839 Hiscott, R.N., Aksu, A.E., Yasar, D., Kaminski, M.A., Mudie, P.J., Kostylev, V.E., MacDonald, 840 J.C., Iser, F.I., Lord, A.R. 2002. Deltas south of the Bosphorus Strait record persistent

842 Hiscott, R.N., Aksu, A.E., Mudie, P.J., Kaminski, M., Abrajano, T., Yasar, D., Rochon, A. 2006. The Marmara Sea Gateway since 16Ka: non-catastrophic causes of paleoceanographic events in the Black Sea at 8.4 and 7.15 ka. In: Yanko-Hombach, V. Gilbert, A.S., Panin, N., Dolukhanov, P. (Eds.), The Black Sea Floor Question: Changes in Coastline, Climate and Human Settlement. Springer, Dordrecht, The Netherlands.

Hughen, K. A., Overpeck, L.C., Anderson, R.F. 1996. The nature of varved sedimentation in the Cariaco Basin, Venezuela, and its palaeoclimatic significance, in Palaeoclimatology and Palaeoceanography from Laminated Sediments, edited by A. E. S. Kemp, pp. 171-183, Geological Society, London.

Itou, M., Matsumura, I., Noriki, S. 2000. A large flux of particulate matter in the deep Japan Trench observed just after the 1994 Sanriku-Oki earthquake, Deep-Sea Research I 4, 1987-1998.

Kaiho, K. 1994. Benthic foraminiferal dissolved-oxygen index and dissolved-oxygen levels in the modern ocean. Geology 22, 719-722.

Kaminski, M.A., Aksu, A., Box, M., Hiscott, R.N., Filipescu, S., Al-Salameen, M. 2002. Late Glacial to Holocene benthic foraminifer in the Marmara Sea: implications for Black SeaMediterranean Sea connections following the last deglaciation. Marine Geology 19, 165202.

Lane-Serff, G.E., Rohling, E.J., Bryden, H., Charnock, H. 1997. Postglacial connection of the Black Sea to the Mediterranean and its relation to the timing of sapropel formation. 
Palaeoceanography 12, 169-174.

863 Lee, J. J., Pawlowski, J., Debenay, J. P., Whittaker, J. E., Banner, F. T., Gooday, A. J., Tendal,

864 O., Haynes, J., Faber, W. W. 2000. Class Foraminifera In: J. J. Lee, G. F. Leedale, P. 865 Bradbury (eds.). An Illustrated Guide to the Protozoa, $2^{\text {nd }}$ Edition. Society of 866 Protozoologists. Allen Press, Lawrence Kansas, 877-951.

867 Le Pichon X., Sengör A. M. C., Demirbag E., Rangin C., Imren C., Armijo R., Görür N., 868 Çagatay M. N., Mercier de Lepinay B., Meyer B., Saatçilar R., Tok B. 2001. The active 869 main Marmara fault. Earth and Planetary Science Letters 192, 595-616.

870 Leventer, A., Williams, D.F., Kennett, J.P. 1982. Dynamics of the Laurentide ice sheet during 871 the last deglaciation: evidence from the Gulf of Mexico. Earth and Planetary Science $872 \quad$ Letters 59, 11-17.

873 Loeblich, A. R., Tappan, H. 1988. Foraminiferal Genera and their Classification, vol. 1-2. Van $874 \quad$ Nostrand Reinhold, New York 970 pp., 847 pl.

875 Major, C.O., Ryan, W., Lercolais, G., Hajdas, I. 2002. Constraints on Black Sea outflow to the 876 Sea of Marmara during the last glacial-interglacial transition. Marine Geology 190, 19-34.

877 Major, C.O., Goldstein, S.L., Ryan, W.B.F., Lercolais, G., Piotrowski, A.M., Hajdas, I. 2006. 878 Quaternary Science Reviews 25, 2031-2047.

879 Mangerud, J., Andersen, S.T., Berglund, B.E., Donner, J.J. 1974. Quaternary stratigraphy of $880 \quad$ Norden, a proposal for terminology and classification. Boreas 3, 109-127.

881 Malcolm, S.J., Price, N.B., 1984. The behaviour of iodine and bromine in estuarine surface 882 sediments. Mar. Chem. 15, 263-271. 
883 Mart, Y., Ryan, W., Çagatay, N., McHugh, C., Giosan, L., Vachtman, D., 2006, Evidence for 884 intensive flow from the Bosporus northwards during the early Holocene. EGU Geophysical Research Abstracts, V. 8, 02572.

886 McHugh, C. M. G., Seeber, L., Cormier, M.-H., Dutton, J., Çagatay, M. N., Polonia, A., Ryan, W. B. F., Görür, N. 2006. Submarine earthquake geology along the North Anatolian Fault

Meric, E., Algan, O. 2007. Paleoenvironments of the Marmara Sea (Turkey) Coasts from Meric, E., Avsar, N., Bergin, F. 2004. Benthic foraminifera of Eastern Aegean Sea (Turkey) systematics and autoecology. Chamber of Geological Engineers of Turkey and Turkish Marine Research Foundation, 18, 306pp. paleontological and sedimentological data. Quaternary International 167, 128-148.

Mudie, P.J., Aksu, A.E., Yasar, D. 2001. Late Quaternary dinoflagellate cysts from the Black, Marmara and Aegean seas: variations in assemblages, morphology and paleosalinity. Marine Micropaleontology 43, 155-178.

Mudie, P.J., Rochon, A., Aksu, A.E., 2002. Pollen stratigraphy of Late Quaternary cores from

Mudie, P.J., Marret, F., Aksu, A.E., Hiscott, R.N., Gillespie, H. 2007. Palynological evidence for Marmara Sea: land-sea correlation and paleoclimatic history. Marine Geology 190, 233260. climatic change, anthropogenic activity and outflow of Black Sea water during the late Pleistocene and Holocene: Centennial- to decadal-scale records from the Black and Marmara Seas. Quaternary International 167, 73-90.

Murray, J. W. 1971. An atlas of British recent foraminiferids. American Elsevier Publications, New York. 244pp. 
907 Murray, J. W., 1986. Living and dead Holocene foraminifera of Lyme Bay, Southern England. 908 Journal of Foraminiferal Research 16:347-352.

909 Murray, J. 1991. Ecology and Palaeoecology of Benthic Foraminifer. Longman Scientific \& $910 \quad$ Technical. 397pp.

911 Murray, J. 2006. Ecology and Applications of Benthic Foraminifera. Cambridge University $912 \quad$ Press. 422pp.

913 Myers, P.G., Wielki, C., Goldstein, S.B., Rohling, E.J., 2003. Hydraulic calculations of 914 postglacial connections between the Mediterranean and the Black Sea. Marine Geology $915 \quad 201,253-267$.

916 Newman, K. R. 2003. Using submerged shorelines to constrain recent tectonics in the Marmara 917 Sea, northwestern Turkey. Department of Geology, Senior Thesis, Smith College: 49pp.

918 Okay, A.I., Demirbag, E., Kurt, H., Okay, N., Kusçu, I. 1999. An active, deep marine strike-slip 919 basin along the North Anatolian fault in Turkey. Tectonics 18, 129-147.

920 Okay, N., Ergun, B. 2005. Source of basinal sediments in the Marmara Sea investigated using 921 heavy minerals in the modern beach sands. Marine Geology 216, 1-15.

922 Ortiz, J.D., O'Connell, S.B., DelViscio, J., Dean, W., Carriquiry, J.D., Marchitto, T., Zheng, Y., 923 vanGeen, A. 2004. Enhanced marine productivity off western North America during warm 924 climate intervals of the past 52 k.y. Geology 32, 521-524.

925 Peterson, L. C., Overpeck, J.R., Kipp, N.G., Imbrie, J. 1991. A high-resolution late Quaternary 926 upwelling record from the anoxic Cariaco Basin, Venezuela. Paleoceanography 6, 99-119.

927 Phleger, F. 1960. Ecology and distribution of Recent foraminifera. John Hopkins Press. 928 Baltimore, MD, $297 \mathrm{pp}$.

929 Polonia A., Cormier M.H., Çagatay M.N., Bortoluzzi G., Bonatti E., Gasperini L., Seeber L., 

B., Blasi A., Busetti M., Eris K., Fabretti P., Fielding E.J., Imren C., Kurt H., Magagnoli A., Marozzi G., Ozer N., Penitenti D., Serpi G., Sarikavak K., 2002, Exploring submarine earthquake geology in the Marmara Sea, EOS Transactions AGU 83 229, 235-236.

934 Polonia, A., Gasperini, L., Amorosi, A., Bonatti, E., Bortoluzzi, G., Çagatay, M. N., Capotondi,

935 L., Cormier, M.-H., Görür, N., McHugh, C. M. G., Seeber, L. 2004 Holocene slip rate of the North Anatolian Fault beneath the Sea of Marmara. Earth and Planetary Science Letters

Rangin, C., Demirbag, E., Imren, C., Crusson, A., Normand, A., Le Drezen, E., Le Bot, A. 2001. Marine Atlas of the Sea of Marmara: Ifremer.

Reichel, T. and Halbach, P. 2007. An authigenic calcite layer in the sediments of the Sea of Marmara-A geochemical marker horizon with paleoceanographic significance. Deep Sea

Renberg, I., 1990. A procedure for preparing large sets of diatom slides form sediment cores. Journal of Paleolimnology 4, 87-90.

Ross, D. A., Degens, E. T. 1974. Recent sediments of the Black Sea, (Eds.) E. T. Degens, D. A. Ross, The Black Sea Geology, Chemistry and Biology, Tulsa: Am. Assoc. Petrol. Geol. Mem. 20, 183-199.

Rossignol-Strick, M. 1995. Sea-land correlation of pollen records in the eastern Mediterranean for the glacial-interglacial transition: Biostratigraphy versus radiometric time-scale. Quaternary Science Reviews 14, 893-915.

Round, F.E.E., Crawford, R.M., Mann, D.G. 1990. Diatoms: Biology and Morphology of the Genera. Cambridge University Press 560pp. 
953 Ryan, W.B.F., Pitman, W.C., Major, C.O., Shimkus, K., Moskalenko, V., Jones, G.A., Dimitrov, 954 P., Görür, N., Sakinç, M., Yüce, H. 1997. An abrupt drowning of the Black Sea shelf. 955 Marine Geology 138, 119-126.

956 Ryan, W.B.F., Major, C.O., Lericolais, G., and Goldstein, S. L. 2003. Catastrophic flooding of 957 the Black Sea. Annual Review Earth Planetary Science 31, 525-254.

958 Schonfeld, J. 1997. The impact of the Mediterranean Outflow Water (MOW) on benthic 959 foraminiferal assemblages and surface sediments at the southern Portuguese continental 960 margin. Marine Micropaleontology 29, 211-236.

961 Schonfeld, J. 2001. Benthic foraminifera and pore-water oxygen profiles: a re-assessment of 962 species boundary conditions at the western Iberian margin. Journal of Foraminiferal Research 31, 86-107.

Sengör, A.M.C., Görür, N., Saroglu, F. 1985. Strike-slip faulting and related basin formation in zones of tectonic escape: Turkey as a case study, in Strike-Slip Deformation, Basin Formation, and Sedimentation, edited by K.T. Biddle, and N. Christie-Blick. Soc. Econ. Paleont. Min. pp. 227-264

968 Sen Gupta, B.K., Machain-Castillo, M.L. 1993. Benthic foraminifera in oxygen-poor habitats. 969 Marine Micropaleontology 20, 183-201.

970 Sen Gupta, B.K., Turner, R.E., Rabalis, N.N. 1996. Seasonal oxygen depletion in continental971 shelf waters of Louisiana- Historical record of benthic foraminifers. Geology 24, 227-230.

972 Sgarella, F., Moncharmont Zei, M. 1993. Benthic foraminifera of the Gulf of Naples (Italy): 973 Systematics and autoecology. Boll. Soc. Paleontologist Italy 32, 145-264.

974 Sidall, M., Rohling, E.J., Almogi-Labin, A., Hemleben, Ch., Meischner, D., Schmelzer, I., 975 Smeed, D.A. 2003. Sea-level fluctuations during the last glacial cycle. Nature 423, 853$976 \quad 858$.

977 Sidall, M., Lawrence, J. P., Helfrich, K. R., Giosan, L. 2004. Testing the physical oceanographic 

implications of the suggested sudden Black Sea infill 8400 years ago. Paleoceanography 19, PA1024, doi:10.1029/2003PA000903.

Siani, G., Paterne, M., Arnold, M., Bard, E., Metivier, B., Tisnerat, N., Bassinot, F. 2000. Radiocarbon reservoir ages in the Mediterranean Sea and Black Sea, Radiocarbon 42, 271280.

983

984

985

986

987

988

989

990

991

992

993

994

995

996

997

998

999

1000

1001

Sperling, M., Schmiedl, G., Hembleben, Ch., Emeis, K.C., Erlenkeuser, H., Grootes, P.M. 2003. Black Sea impact on the formation of eastern Mediterranean sapropel S1? Evidence from the Marmara Sea. Palaeogeography, Palaeoclimatology, Palaeoecology 190, 9-21.

Stanley, D.J., Blanpied, C. 1980. Late Quaternary water exchange between the eastern Mediterranean and the Black Sea. Nature 266, 537-541.

Stuvier M., and Reimer, P.J., 1993. Extended 14C database and revised CALIB radiocarbon calibration program. Radiocarbon 35, 215-230.

Svitoch, A.A., 1999. Caspian Sea level in the Pleistocene: hierarchy and position in the paleogeographic and chronological records. Oceanology 39, 94-101.

Thomas E., Gapotchenko T., Varekamp J., Mecray E.L., Buchholtz ten Brink M.R. 2000. Benthic foraminifera and environmental changes in Long Island Sound. Journal of Coastal Research 16, 641-655.

Thunell, R.C., Williams, D.F. 1989. Glacial-Holocene salinity changes in the Mediterranean Sea: hydrographic and depositional effects. Nature 338, 493-496.

Thunell, R., Tappa, E., Varela R., Llano, M., Astor, Y., Muller-Karger, F., Bohrer, R. 1999. Increased marine sediment suspension and fluxes following an earthquake. Nature 398, 233236.

Tyson, R.V., Pearson, T.H. 1991. Modern and ancient continental shelf anoxia: an overview. Geological Society Special Publication 58, 1-24. 
1002 Vaught, K.C., Abbott, R.T., Boss, K.J. 1989. Classification of the living Mollusca. American 1003 Malacologist. Melbourne, Fla. U.S.A., 204pp.

1004 Yanko, V. V., Troitskaja, T. S. 1987. Pozdne-chetvertichnye foraminifery Chernogo morya. Late 1005 Quaternary Foraminifera of the Black Sea. Akademiya Nauk SSSR. Institut Geologii I 1006 Geofiziki Trudy 694, 111pp.

1007

1008

1009 
1011 Figure 1. (a). Satellite image of the Aegean Sea, Marmara Sea and Black Sea corridor showing 1012 Marmara's significant location as a gateway between the Aegean and Black Seas, and the 1013 location of the Dardanelles and Bosporus Straits. (b) Multibeam bathymetry of the main 1014 Marmara Sea basins (Rangier et al., 2001). Boxes show the location of the studied areas in 1015 Imrali, Prince Islands and Çekmece.

1016

1017 Figure 2. Multibeam bathymetry of the Imrali study area showing the location of high resolution 1018 subbottom profiles, CHIRP, navigation tracks (red lines) and location of core transect (red dots). 1019 The studied cores IM05 and IM03 are located at -152 and -298 m of water depth, respectively. 1020 The Marmara Lake high-stand was at -85 m (Çagatay et al., 2000; Algan et al., 2001; Newman, $10212003)$.

1022

1023 Figure 3. (a). Multibeam bathymetry of the Imrali study area showing the location of the cores 1024 and CHIRP subbottom profile (Line imc04-06). Modified after McHugh et al., 2006. (b). CHIRP 1025 subbottom profile extending from -90 to $-200 \mathrm{~m}$. Offsets due to normal fault activity are $15 \mathrm{~m}$ 1026 and $1.5 \mathrm{~m}$. Also shown an offset of $13.5 \mathrm{~m}$ due to possibly slumping and/or related fault activity.

1027 (c). After reconstruction of fault related offsets, Core IM05 is located at $-115 \mathrm{~m}$, there is a 1028 paleoshoreline at $-95 \mathrm{~m}$, and the lake high-stand paleoshoreline at $-87 \mathrm{~m}$. Correlation of the 1029 lithology and age to the seismic line reveals the lacustrine-marine transition occurred at $\sim 12.0 \mathrm{ka}$ 1030 BP (brown reflector). Turquoise surface delineates the sea-floor and sediment deposited during 1031 the Holocene. 
1033 Figure 4. Lithology and facies of Core IM05 showing the lacustrine barren stage (Facies 1, 400$1034365 \mathrm{~cm}$ ) and lacustrine fertile (Facies 2, 365-275 cm). The transition from lacustrine to marine 1035 (Facies 3) is marked by a bed of coarse sand with flat, well-rounded pebbles, and sand laminae 1036 above $(275$ to $260 \mathrm{~cm}$ ). Marine muds and fauna characterize the core from 260 to $0 \mathrm{~cm}$ (Facies $10374)$.

1039 Figure 5. Sedimentation rates calculated from the slope of the line for Core IM05 and Core 6 on 1040 the Imrali and Prince Islands margin, respectively. Sedimentation rates for the lacustrine stage 1041 are two orders of magnitude greater than the marine. Sedimentation rates for the Holocene are 1042 comparable for the southern and northern margins.

1044 Figure 6. The physical properties of Core IM05 (p-wave velocity, bulk density, and magnetic 1045 susceptibility) show the changes that occurred from the barren lake stage (Facies 1), to the fertile 1046 lake (Facies 2), due to the marine incursion (Facies 3) to fully marine conditions (Facies 4).

1048 Figure 7. Benthic and planktonic foraminferal assemblages from the Imrali outer shelf exhibit 1049 major faunal and ecological shifts due to rapidly changing environmental conditions. Most 1050 foraminifers are grouped by genus due to the similar ecological preferences of species (Bulimina 1051 spp., Brizalina spp.) A. tepida is restricted to shallow water, marsh environments while $A$. 1052 beccarii is a highly adaptable species. $H$. balthica is associated to stratification of the water 1053 column. G. affinis equates with high organic flux and productivity. Ages are reported as 
1054 radiocarbon, calibrated, and some (at 150 and $25 \mathrm{~cm}$ ) were calculated from the sedimentation 1055 rates of $0.02 \mathrm{~cm} / \mathrm{yr}$.

1056

1057 Figure 8. (a). Stable oxygen isotope records of Cores IM05 and IM03. Ages are shown as 1058 calibrated years BP. Both cores isotope values range from 2.2 to $1.2 \mathrm{\delta} 18 \mathrm{O} \%$ o and show an overall 1059 trend to lighter values interpreted as warming and freshening. Heavy values in both cores are 1060 interpreted as a high salinity and low temperature signal. (b). Correlation of carbon isotopes 1061 between Cores IM05 and IM03. Both cores show an overall trend to less depleted values from 10622.5 to $-0.5 \delta^{13} \mathrm{C}$ and uniform values after $\sim 6 \mathrm{ka} \mathrm{BP}$.

1063

1064 Figure 9. (a). Sediment coring sites along the outer shelf of Prince Islands. Water depth contours 1065 are given in meters. (b). Subbottom profile (CHIRP) showing a -92 m terrace, lacustrine surface 1066 (brown), and marine Holocene sediments above (blue). The age of the sediments above the 1067 lacustrine surface, $\sim 12 \mathrm{ka} \mathrm{BP}$, is in calibrated years.

1069 Figure 10. Lithostratigraphic columns for Cores 8, 6, 5, and 7 recovered from the Prince Islands 1070 outer shelf. The sediments are generally sandy towards the base of the cores where they contain 1071 reworked lacustrine and marine shells indicating that the lacustrine- marine transition was very 1072 close but not penetrated by the cores possibly due to indurated or sandier strata. The sediments 1073 fine upwards to silty clays and contain marine faunas. Ages reported in calibrated years BP.

1075 Figure 11. Foraminiferal species in Core 6. The low oxygen concentration foraminifers are 1076 represented by Bulimina spp., Brizalina spp. and by C. carinata. Bulimina aculeata dominates 
1077 Bulimina spp. and Brizalina spathulata and Brizalina catanensis dominate the Brizalina spp. As

1078 in Core IM05, C. carinata is the first colonizer after the marine incursion. The marsh shallow

1079 water foraminifers are represented by Elphidium spp. (E. crispum, E. articulatum, E. macellum)

1080 and Ammonia spp. (A. tepida, A. compacta, A. beccarii). After the initial marine incursion A.

1081 tepida, the marsh shallow water species, disappears and Elphidium spp. greatly diminishes in

1082 abundance. A homogenite deposit is present from 150 to $100 \mathrm{~cm}$, Post $6 \mathrm{ka}$ BP the environment 1083 becomes stable as shown by the lack of changes in foraminifers.

1084

1085 Figure 12. Br content estimated from XRF scanning data (in counts/sec). (a). Cores scanned from 1086 the Prince Islands shelf. (b). Cores scanned from the northern shelf (Çekmece). Values indicate 1087 freshwater-derived organic matter (less than 200 counts/sec), whereas higher than that limit are 1088 indicative of marine organic matter. Calibrated dates at their corresponding levels in the cores 1089 are also shown.

1090

1091 Figure 13. Calcium carbonate wt\% for the Prince Islands and Çekmece cores. Values are greatest $1092(25-40 \mathrm{wt} \%)$ during the lacustrine stage and immediately above the marine incursion.

1093

1094 Figure 14. (a). Water depth in meters and core location along the Çekmece outer shelf. (b).

1095 Subbottom profile (CHIRP) showing the $-87 \mathrm{~m}$ high-stand lake plaeoshoreline, a $-92 \mathrm{~m}$ 1096 paleoshoreline, the late Pleistocene lacustrine surface (brown), and marine Holocene sediments 1097 above (turquoise surface). 
1099 Figure 15. Lithostratigraphic columns of cores taken in the northern Çekmece margin between -

110093 and $-118 \mathrm{~m}$ of water depth. Mollusk assemblages (Dreissena sp., Theodoxus sp.) indicate

1101 lacustrine sediments in Core 2 from 50 to $123 \mathrm{~cm}$ and at the base of Core 1. Ages are reported in

1102 calibrated years BP. Lacustrine sediments are silt rich and contain charcoal fragments.

1103 Unfossiliferous layers of indurated clays, possibly diagenetically altered by carbonate

1104 cementation, separate the lacustrine and marine sediments. Marine sediments are primarily

1105 composed of silty clays with abundant marine mollusks and benthic and planktonic foraminifers.

1106 Cores 1 and 3 are sandier and contain reworked intervals manifested by the old over young ages

1107 and the mixing of marine and lacustrine shells.

1108

1109 Figure 16. Benthic and planktonic foraminiferal assemblages from the Çekmece outer shelf

1110 exhibit similar ecological shifts as those of Imrali and Prince Island shelves. Core 1 as in Core 6

1111 shows the low oxygen concentration foraminifers dominated by B. aculeata, B. spathulata, B.

1112 catanensis, and C. carinata. A marsh shallow water environment is indicated by A. tepida and E.

1113 crispum that dominates the Elphidium spp. Hyalinea balthica and Globobulimina affinis show

1114 shifts in their abundance from approximately 11.5 to $8.2 \mathrm{ka} \mathrm{BP}$ possibly related to the Younger

1115 Dryas and Black Sea outflow.

1117 Figure 17. Summary of the lithostratigraphy and biostratigraphy correlated to a calibrated 1118 radiocarbon chronology permits to reconstruct a sequence of events for the Black Sea-Marmara-

1119 Mediterranean corridor as documented by this study. The bases of the lithostratigraphic 1120 sequences provide evidence for Marmara Lake during glacial times. From 15.5 ka BP to 14.5

1121 ka BP the lake was supplied with glacial meltwaters from the Black Sea (a lake at this time) that 
1122 spilled into the Marmara Lake and into the Aegean Sea. The Bolling-Allerod brought warm 1123 conditions to Marmara Lake from $\sim 14.5 \mathrm{ka}$ to $13.0 \mathrm{ka}$. Evaporative conditions prior to the marine 1124 incursion could have contributed to a lake drawdown with formation of the $-95 \mathrm{~m}$ terrace, which 1125 could have also been formed by wave erosion. The incursion of marine waters into Marmara Sea 1126 occurred at $12 \mathrm{ka} \mathrm{BP}$. At this time the Black Sea was either isolated or provided a very weak 1127 outflow to Marmara Sea. A standstill was documented from 11.5 to $10.5 \mathrm{ka} \mathrm{BP}$ and interpreted 1128 as the Younger Dryas event. Sea-level continued to rise and there is evidence for strong outflow 1129 from the Black Sea at $\sim 9.2 \mathrm{ka} \mathrm{BP}$. The modern two-layer circulation was well established by 6 $1130 \mathrm{ka}$ BP when sea level reached close to the present shoreline. 
Table 1. Radiocarbon and calibrated ages for the studied cores.

\begin{tabular}{|c|c|c|c|c|c|c|c|}
\hline Core I.D. & $\begin{array}{c}\text { Depth } \\
\text { mbsf }\end{array}$ & $\begin{array}{c}\text { Core } \\
\text { Int. }(\mathbf{c m}) \\
\end{array}$ & Type & Mollusk & $\begin{array}{l}\text { 14C } \\
\text { Age }\end{array}$ & $\begin{array}{c}\text { Age } \\
\text { Error }\end{array}$ & $\begin{array}{c}* \text { Calibrated } \\
\text { age ka }\end{array}$ \\
\hline MedEx05-1 & 102.60 & 60 & mollusk & Corbula sp. & 10600 & 45 & 11.73 \\
\hline MedEx05-1 & 102.95 & 95 & foraminifera & & 9910 & 60 & 10.74 \\
\hline MedEx05-1 & 103.00 & 100 & mollusk & Corbula sp. & 10500 & 50 & 11.52 \\
\hline MedEx05-2 & 93.95 & 30 & mollusk & $\begin{array}{l}\text { Lucinella sp. } \\
\text { Gouldia sp. }\end{array}$ & 8760 & 55 & 9.36 \\
\hline MexEx05-3 & 93.20 & 20 & mollusk & $\begin{array}{l}\text { Lucinella sp. } \\
\text { Gouldia sp. }\end{array}$ & 5000 & 40 & 5.26 \\
\hline MexEx05-3 & 93.25 & 25 & mollusk & $\begin{array}{l}\text { Lucinella sp. } \\
\text { Gouldia sp. }\end{array}$ & 10300 & 50 & 11.21 \\
\hline MedEx05-3 & 93.50 & 50 & foraminifera & & 6900 & 35 & 7.35 \\
\hline MexEx05-5 & 93.00 & 70 & mollusk & $\begin{array}{c}\text { Lucinella sp. } \\
\text { Gouldia sp. }\end{array}$ & 9890 & 50 & 10.70 \\
\hline MexEx05-5 & 93.10 & 80 & mollusk & $\begin{array}{l}\text { Lucinella sp. } \\
\text { Gouldia sp. }\end{array}$ & 10450 & 80 & 11.46 \\
\hline MedEx05-6 & 98.5 & 100 & foraminifera & & 5350 & 45 & 5.64 \\
\hline MedEx05-6 & 99.10 & 160 & foraminifera & & 9280 & 60 & 10.00 \\
\hline MedEx05-6 & 99.25 & 175 & mollusk & $\begin{array}{l}\text { Lucinella sp. } \\
\text { Gouldia sp. }\end{array}$ & 9720 & 55 & 10.50 \\
\hline MedEx05-6 & 99.52 & 202 & mollusk & Corbula sp. & 10600 & 40 & 11.74 \\
\hline \multirow[t]{2}{*}{ Core IM03 } & 299.60 & 150 & foraminifera & & 5260 & 50 & 5.50 \\
\hline & 300.40 & 230 & foraminifera & & 5420 & 80 & 5.72 \\
\hline \multirow[t]{8}{*}{ Core IM05 } & 152.15 & 55 & foraminifera & & 3440 & 25 & 3.24 \\
\hline & 152.60 & 100 & foraminifera & & 4700 & 40 & 4.85 \\
\hline & 152.60 & 200 & foraminifera & & 8590 & 40 & 9.15 \\
\hline & 154.05 & 245 & mollusk & clam & 11500 & 75 & $12.95 * *$ \\
\hline & 154.15 & 254 & foraminifera & & 10350 & 45 & 11.25 \\
\hline & 154.21 & 260 & mollusk & clam & 10650 & 40 & 11.83 \\
\hline & 154.55 & 295 & mollusk & Dreissena sp. & 13000 & 65 & 14.66 \\
\hline & 155.14 & 354 & mollusk & Dreissena $s p$. & 13150 & 60 & 14.95 \\
\hline
\end{tabular}

*Calibrated ages were obtained by applying Sinai et al. (2000) reservoir corrections and converted to calendar years with the CALIB 5.0 program (Stuvier and Reimer, 1993). **Possibly reworked. 
Figure 1

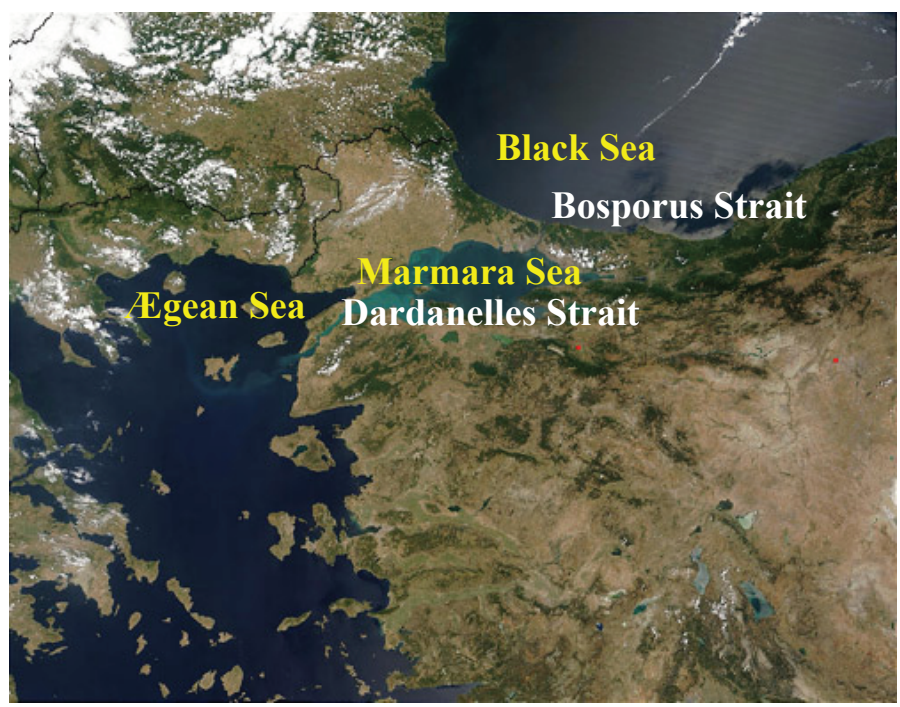

(a)

(b)

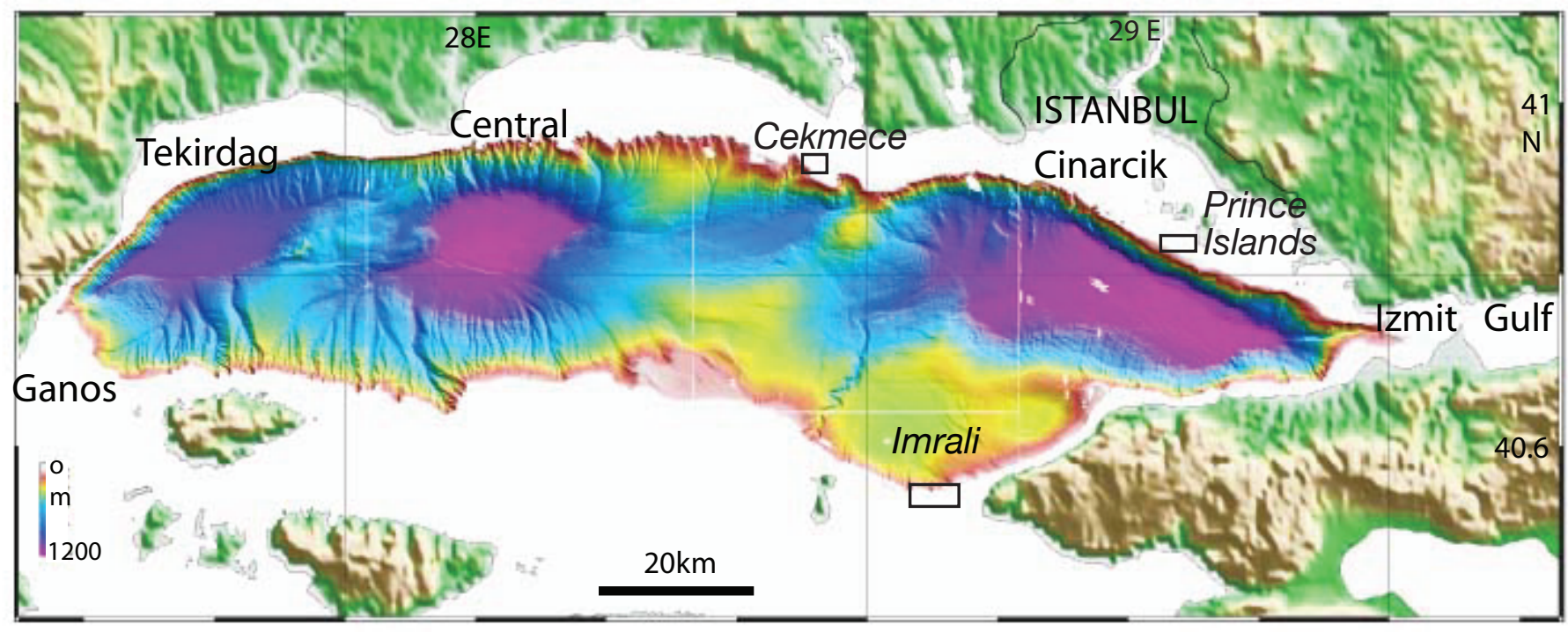


Figure 2.

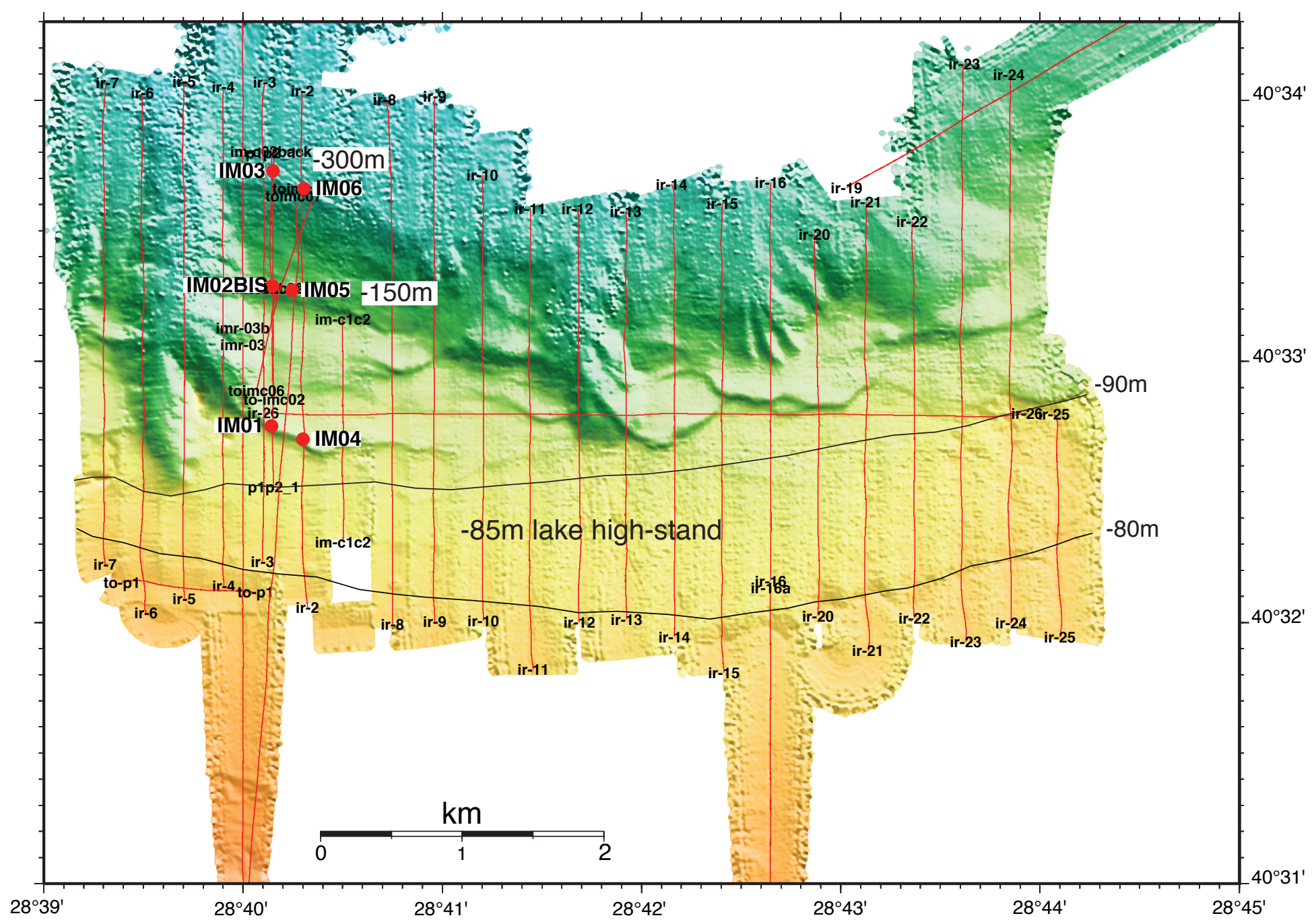


Figure 3

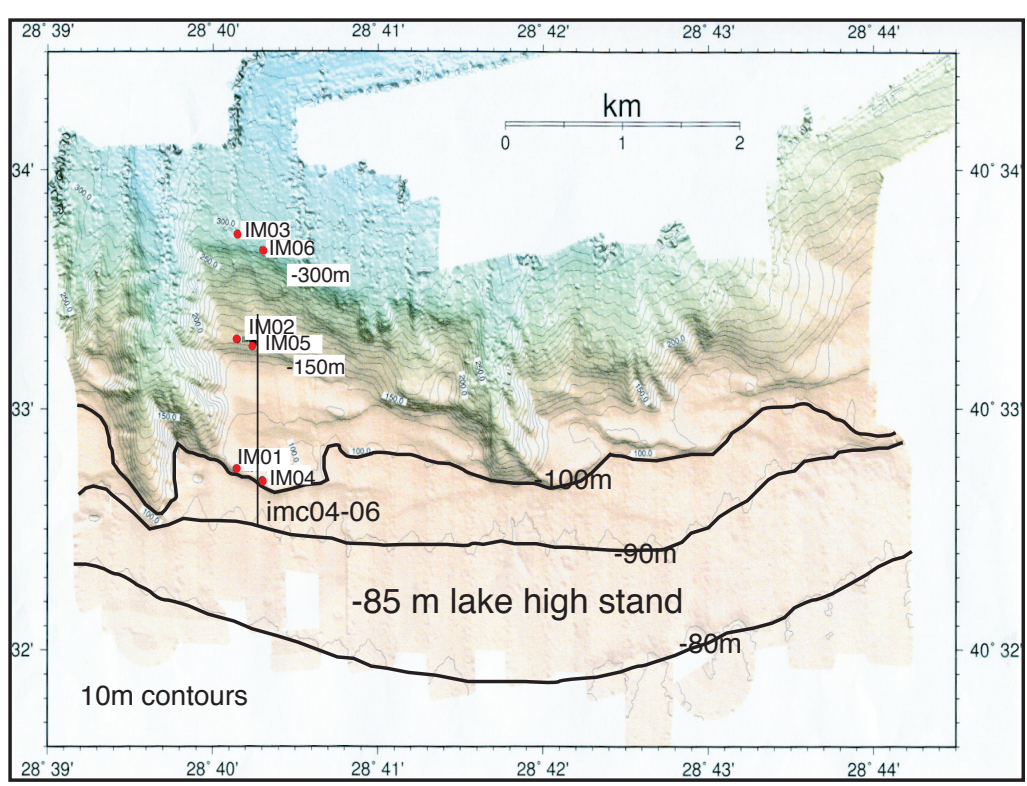

(a)

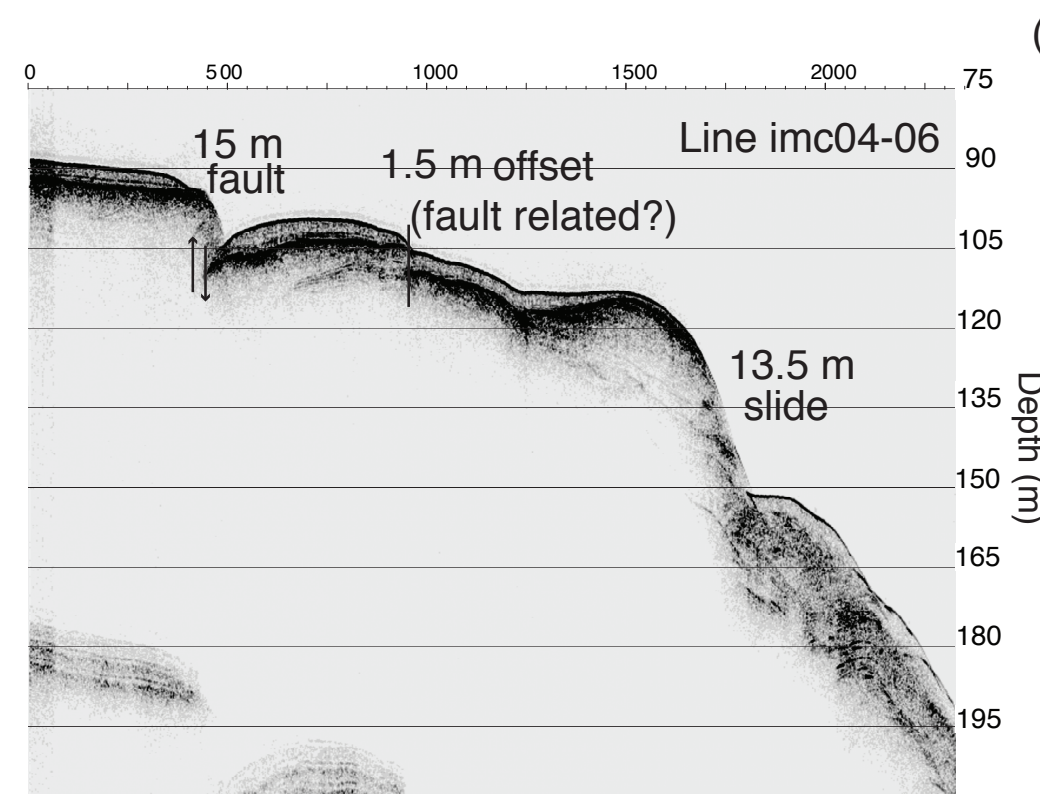

(b)

(c)

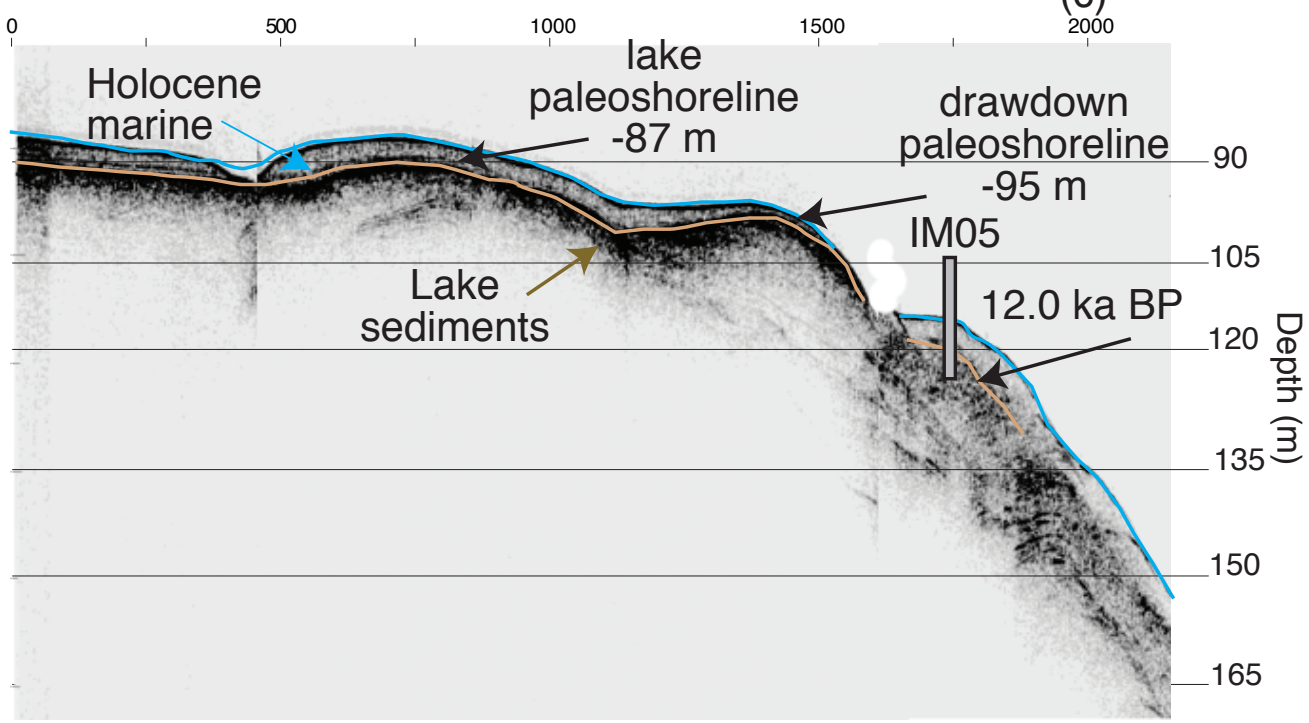


Figure 4

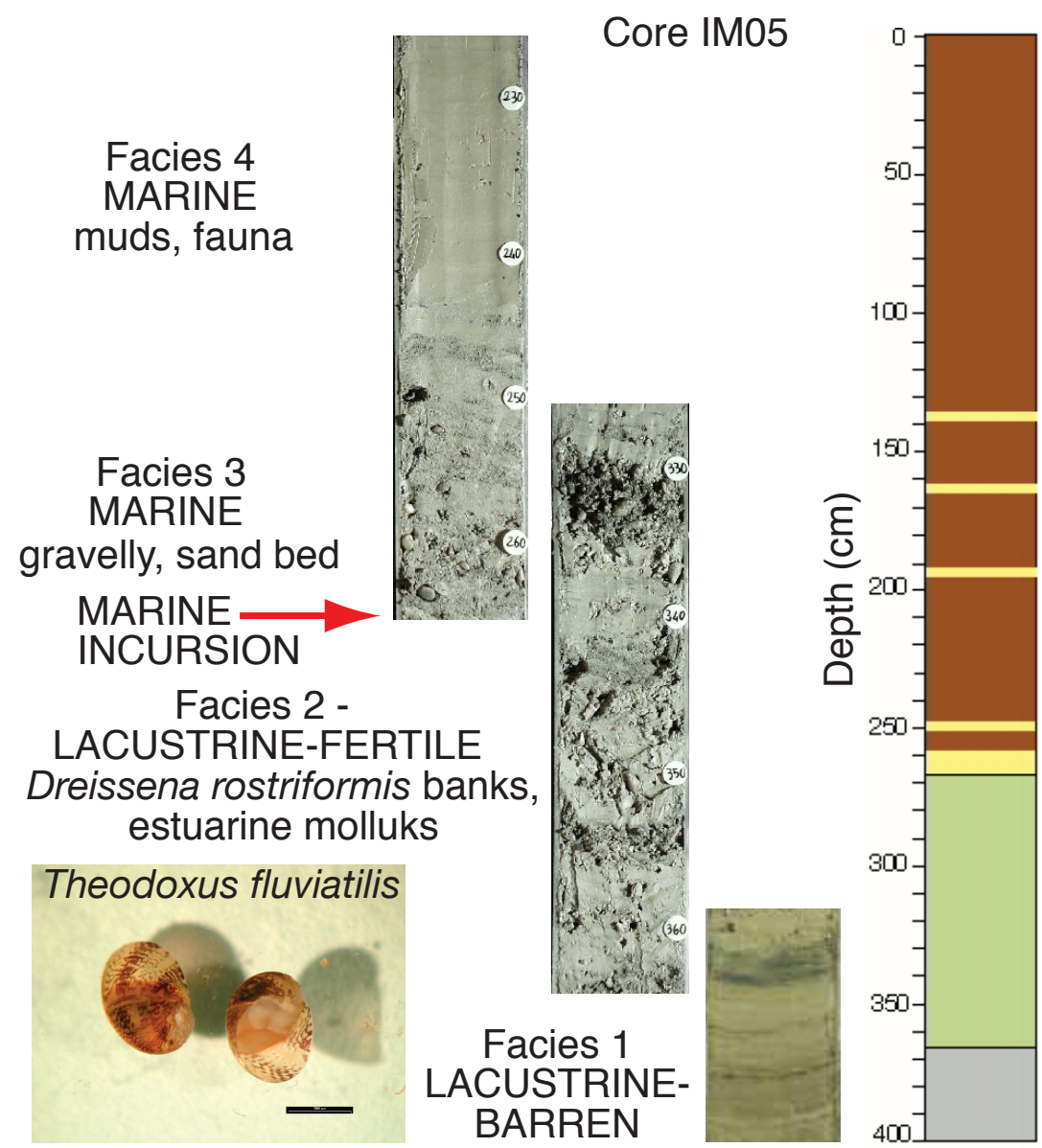




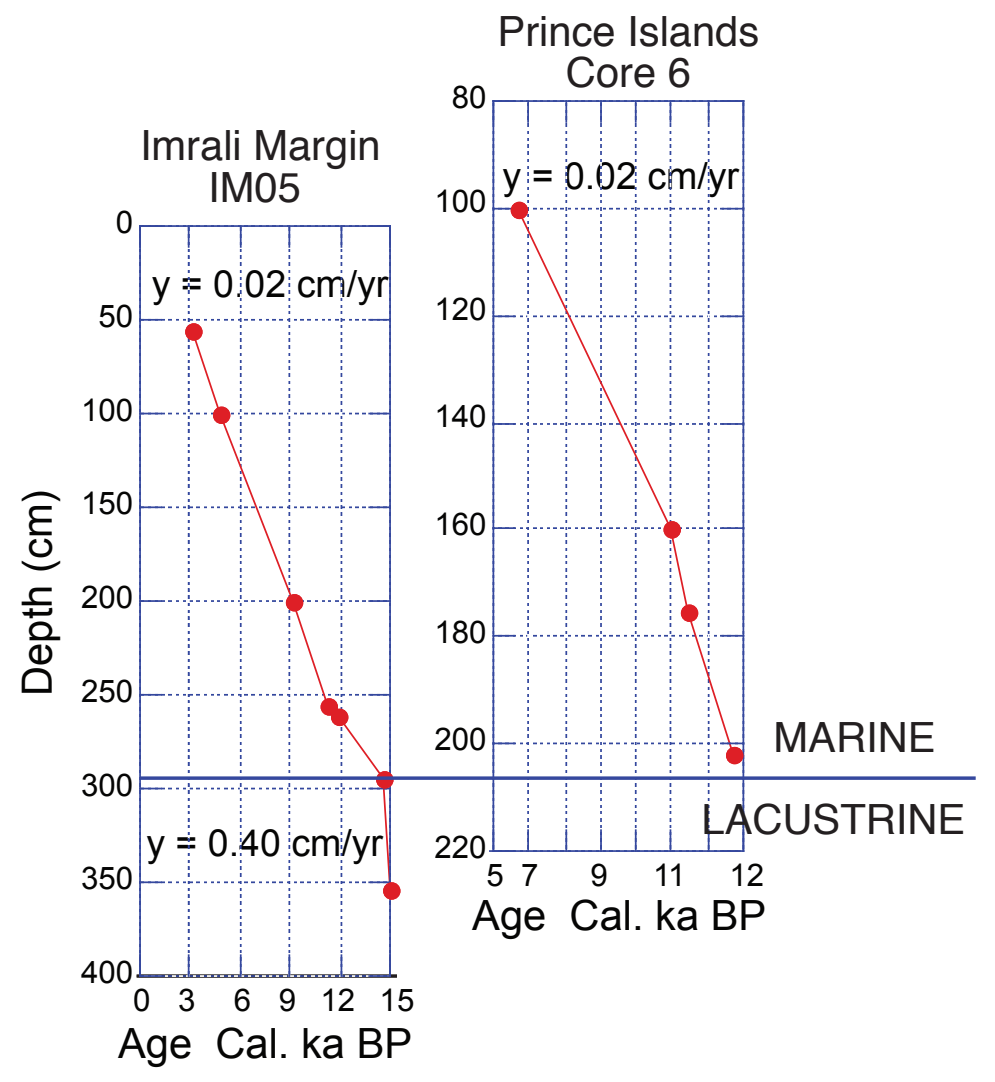




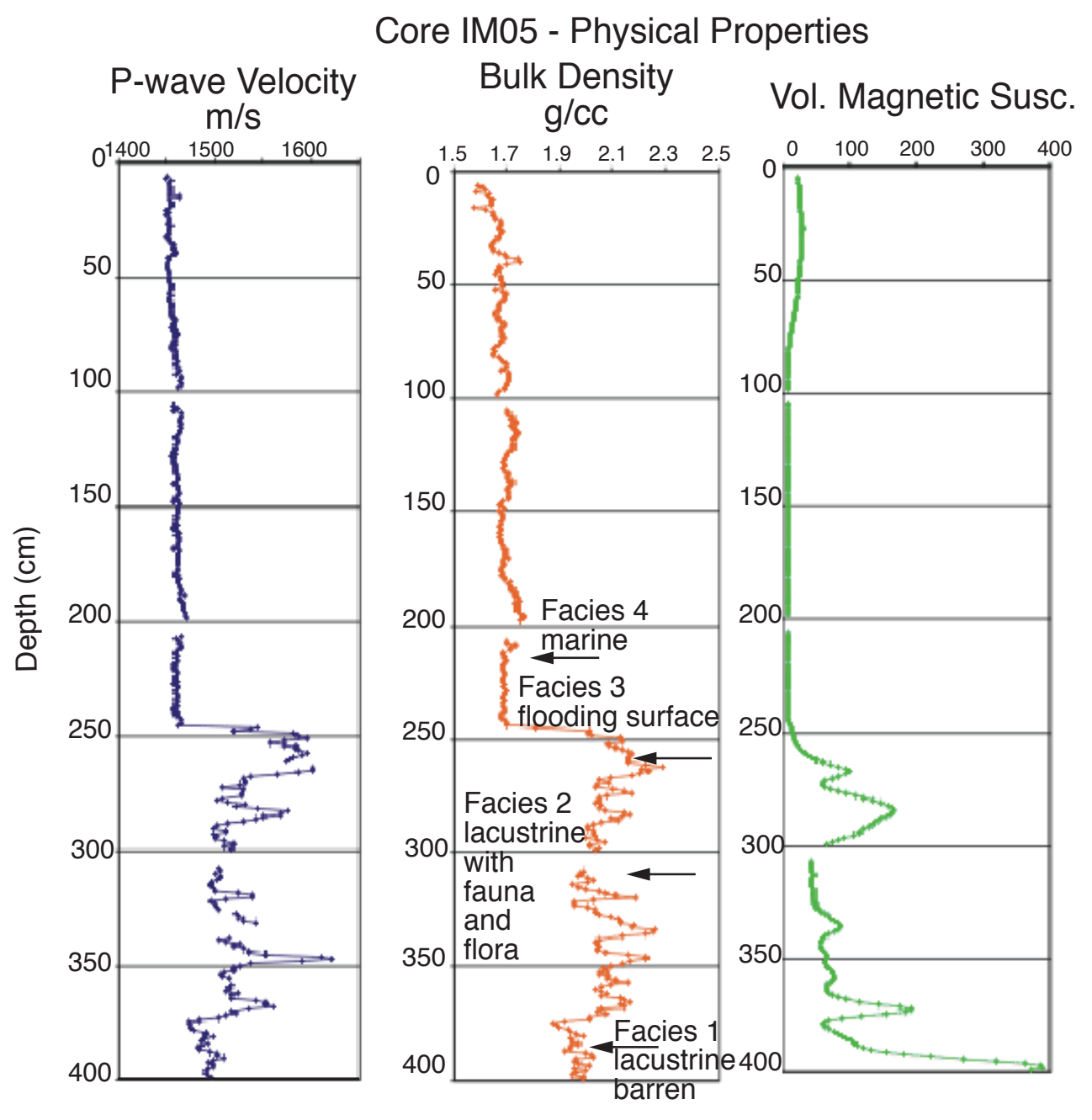


Figure 7

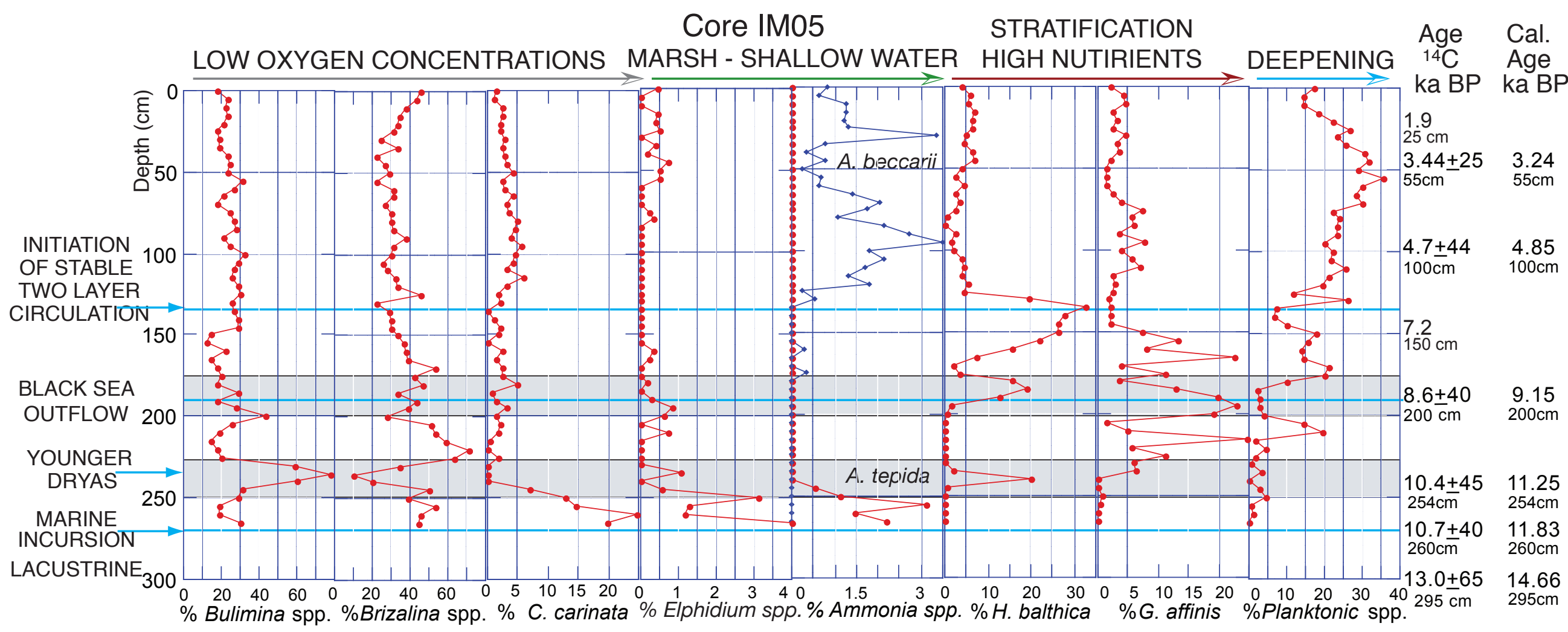




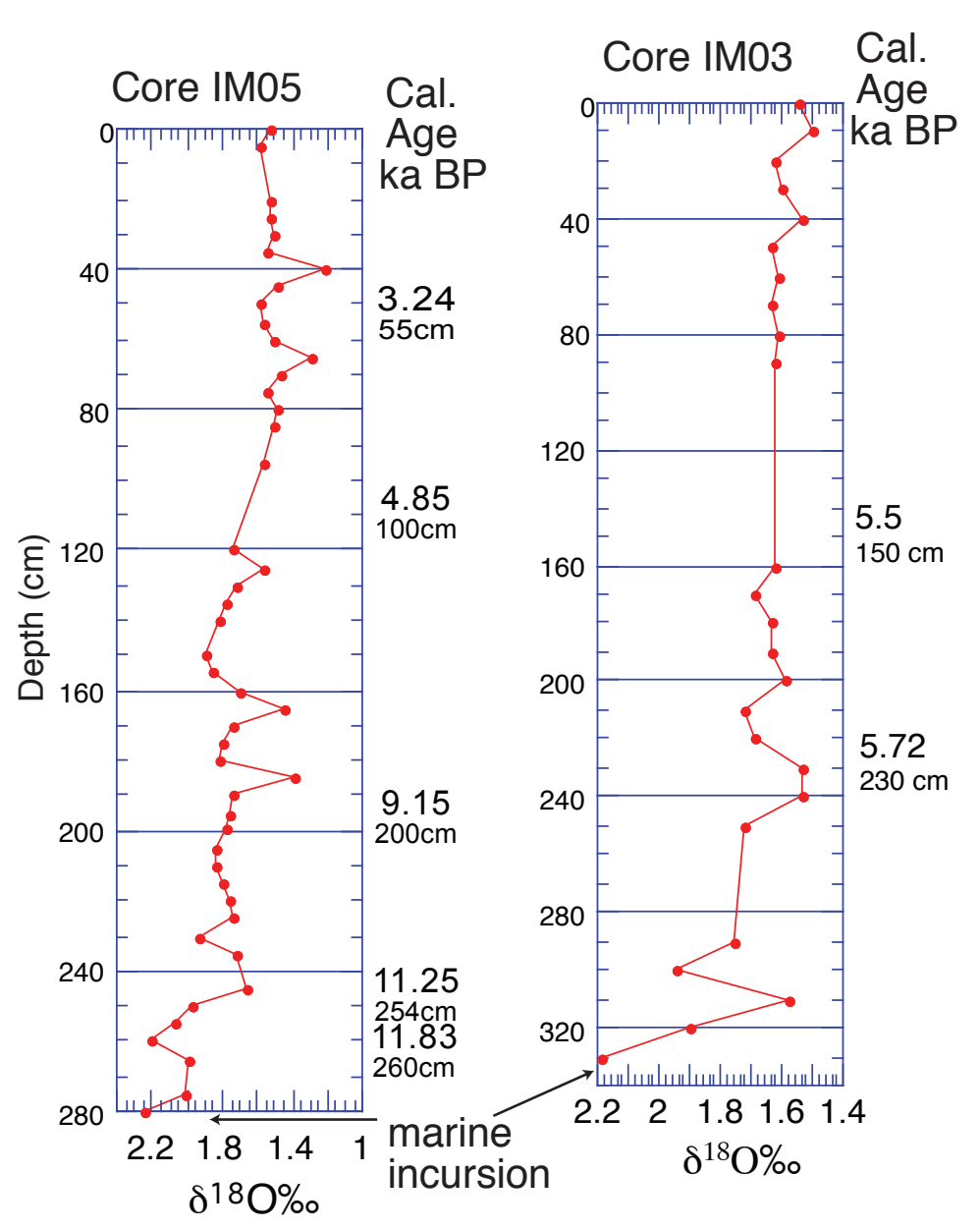

(a) $\quad$ Figure 8

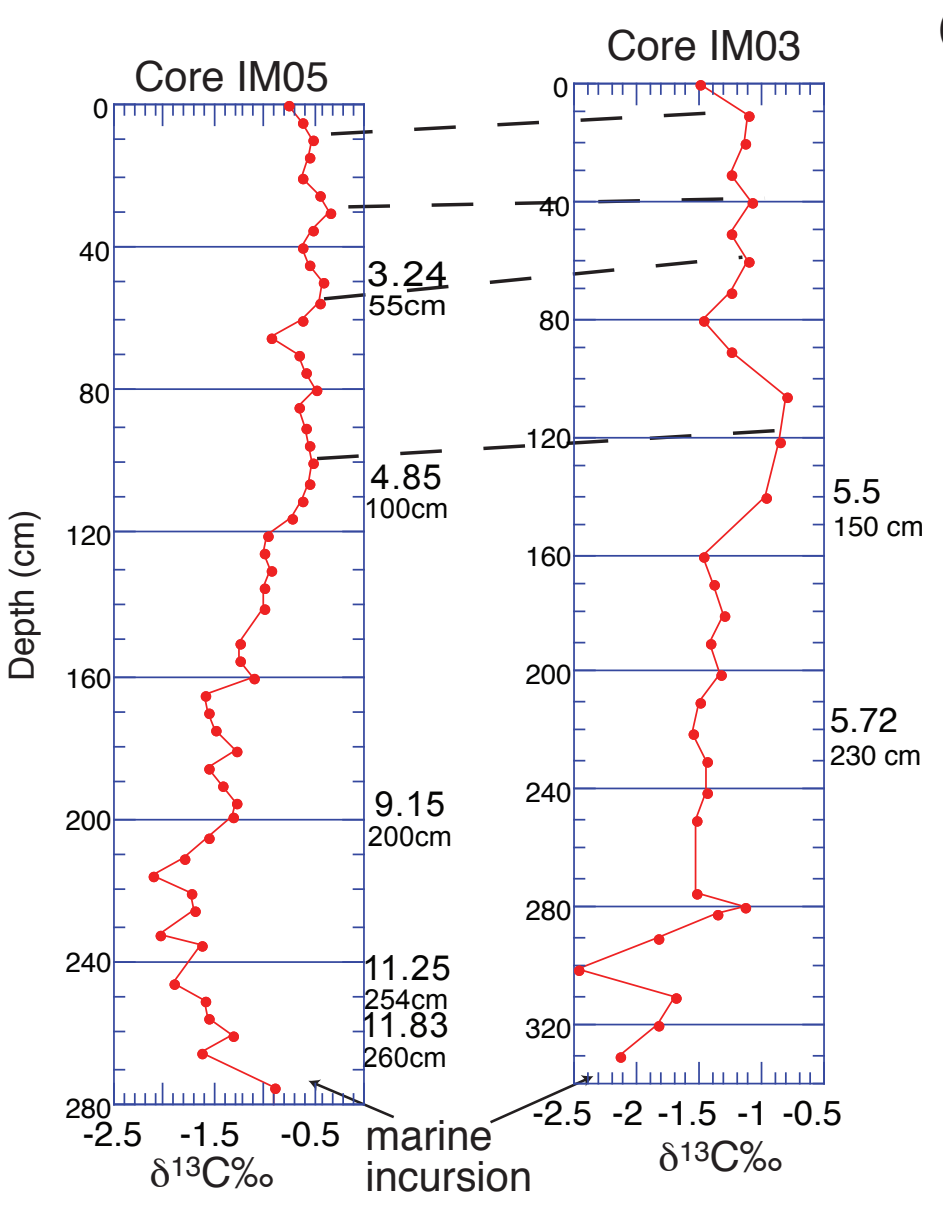


(b)

(a)

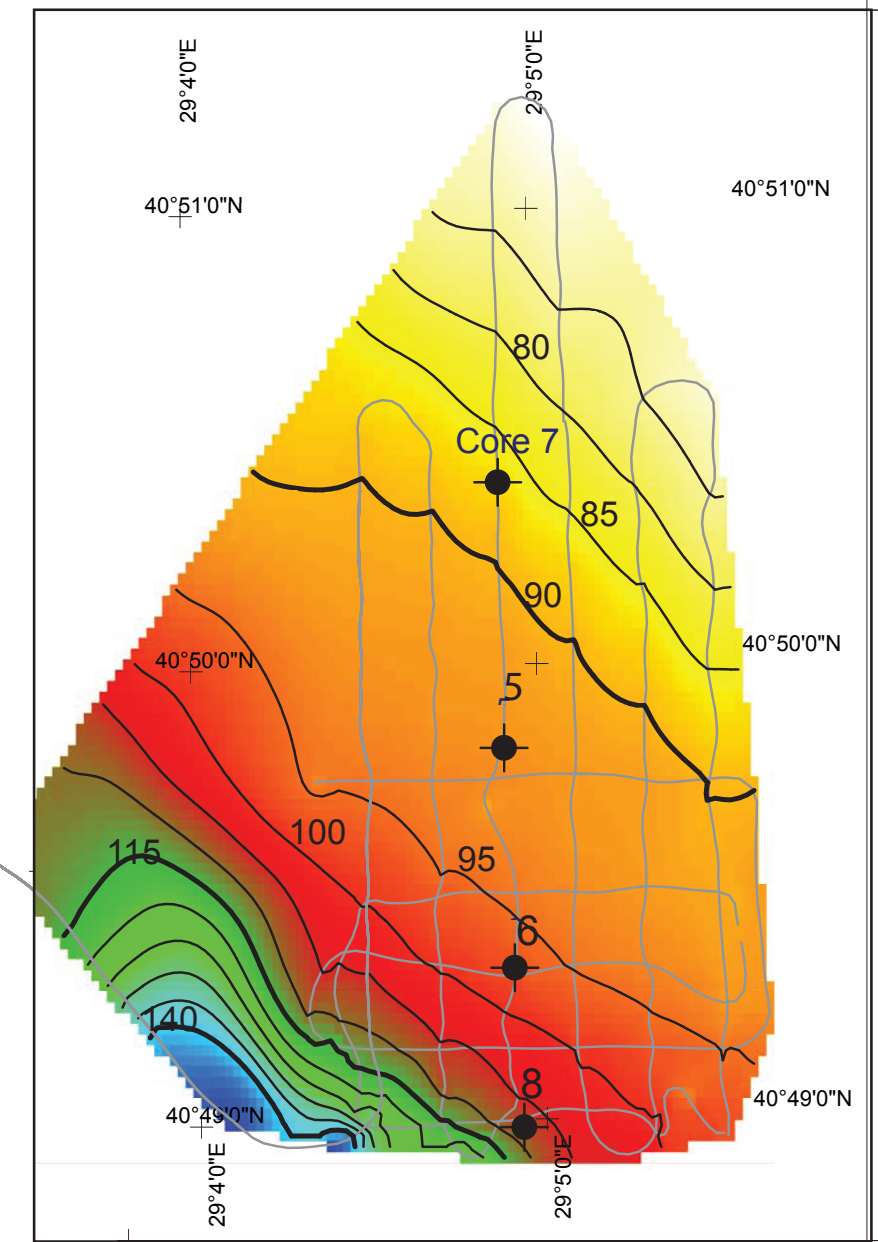

Figure 9

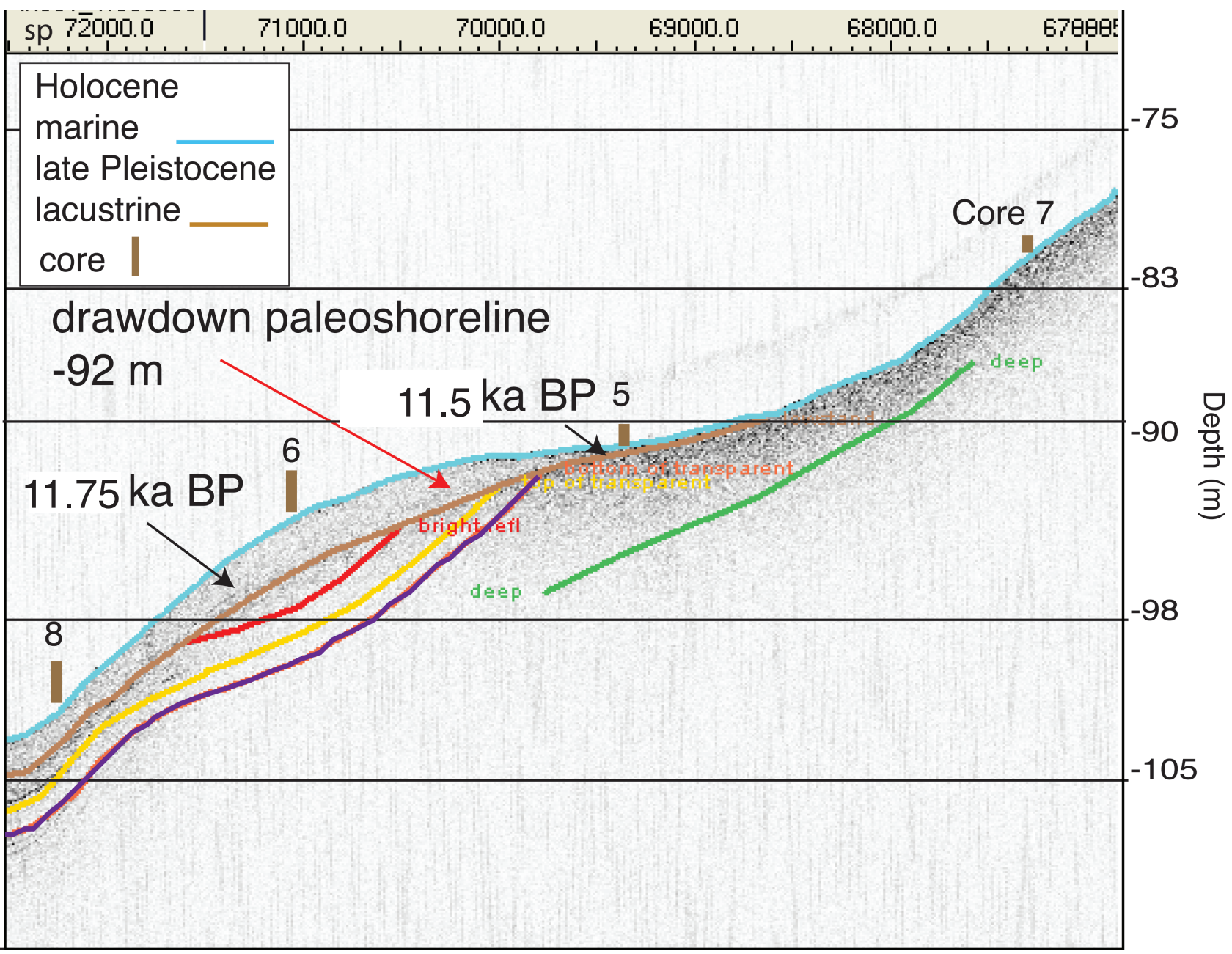


Figure 10.

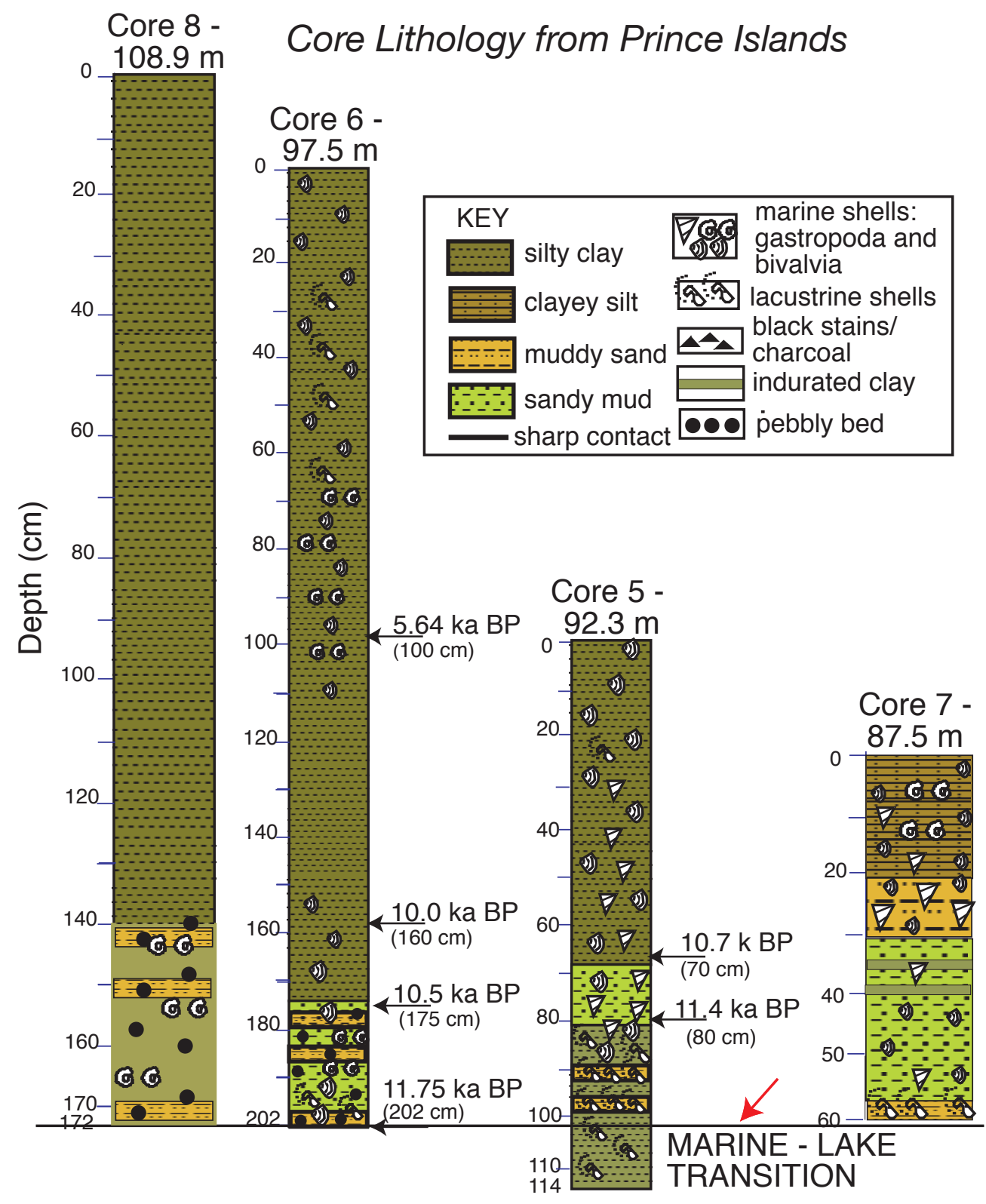


Figure 11

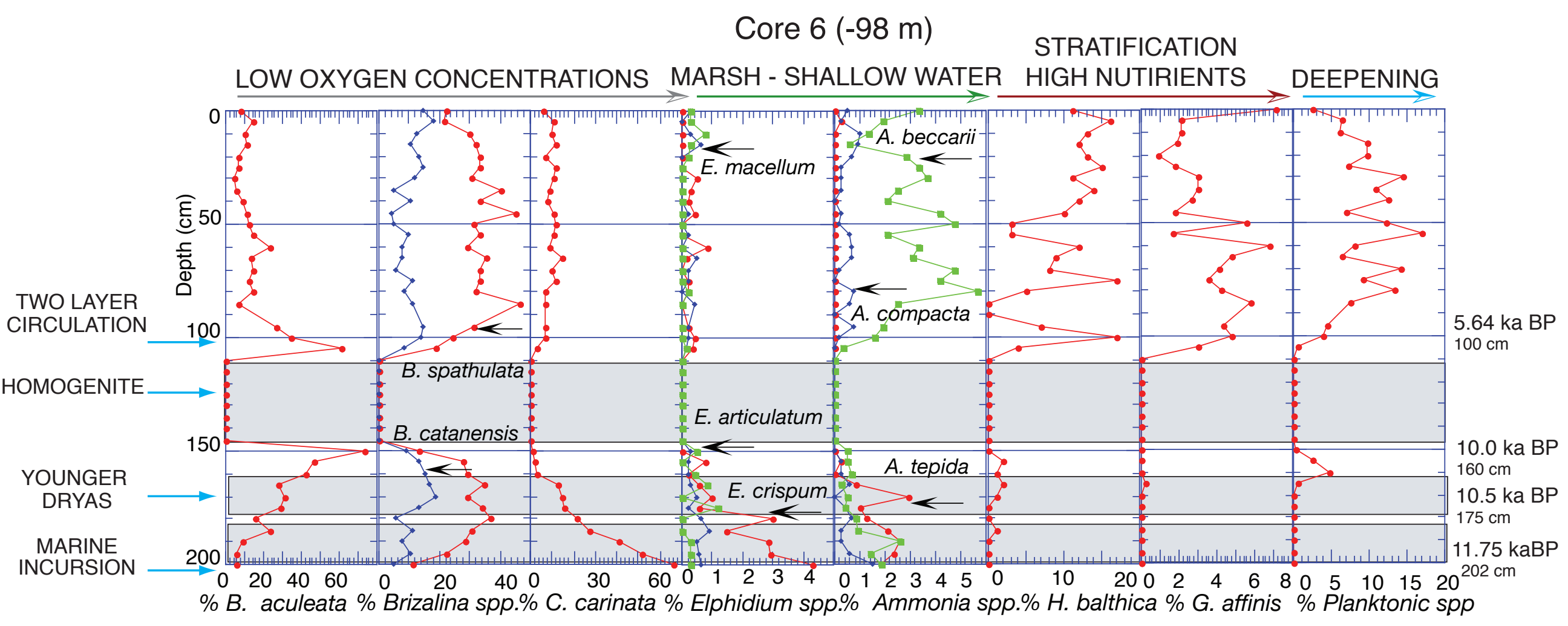


(a)

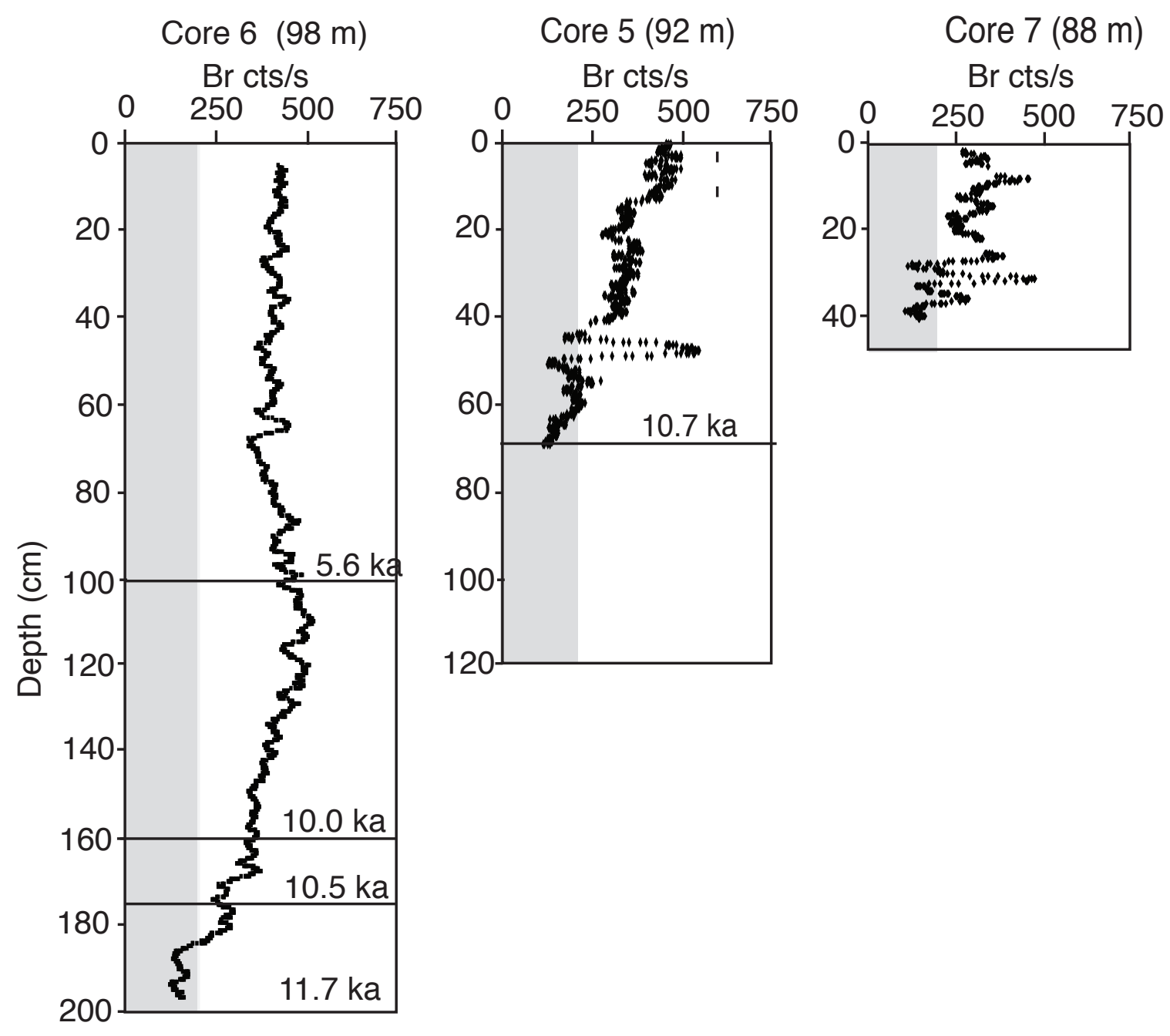

(b)

Core $4(118 \mathrm{~m}) \quad$ Core $1(102 \mathrm{~m}) \quad$ Core $2(93 \mathrm{~m}) \quad$ Core $3(93 \mathrm{~m})$

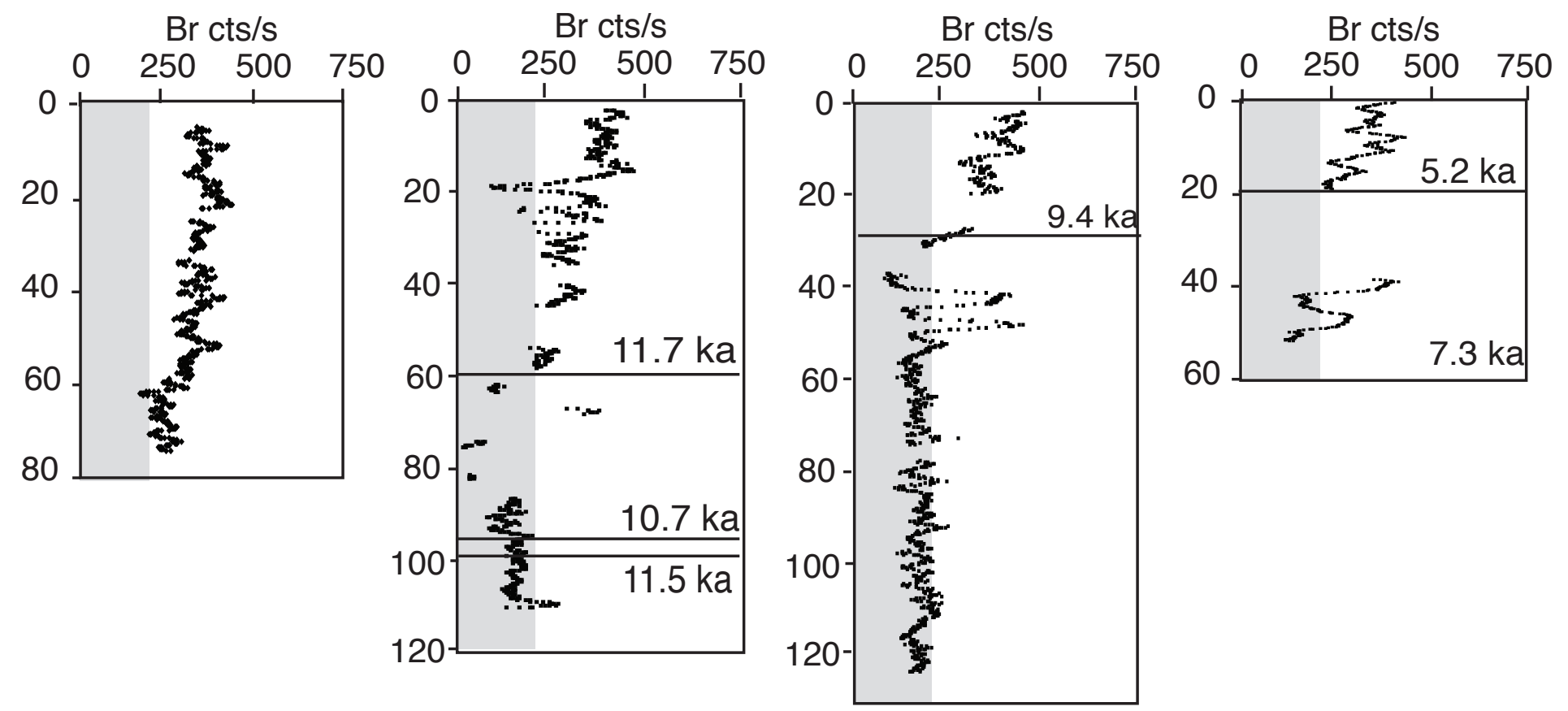




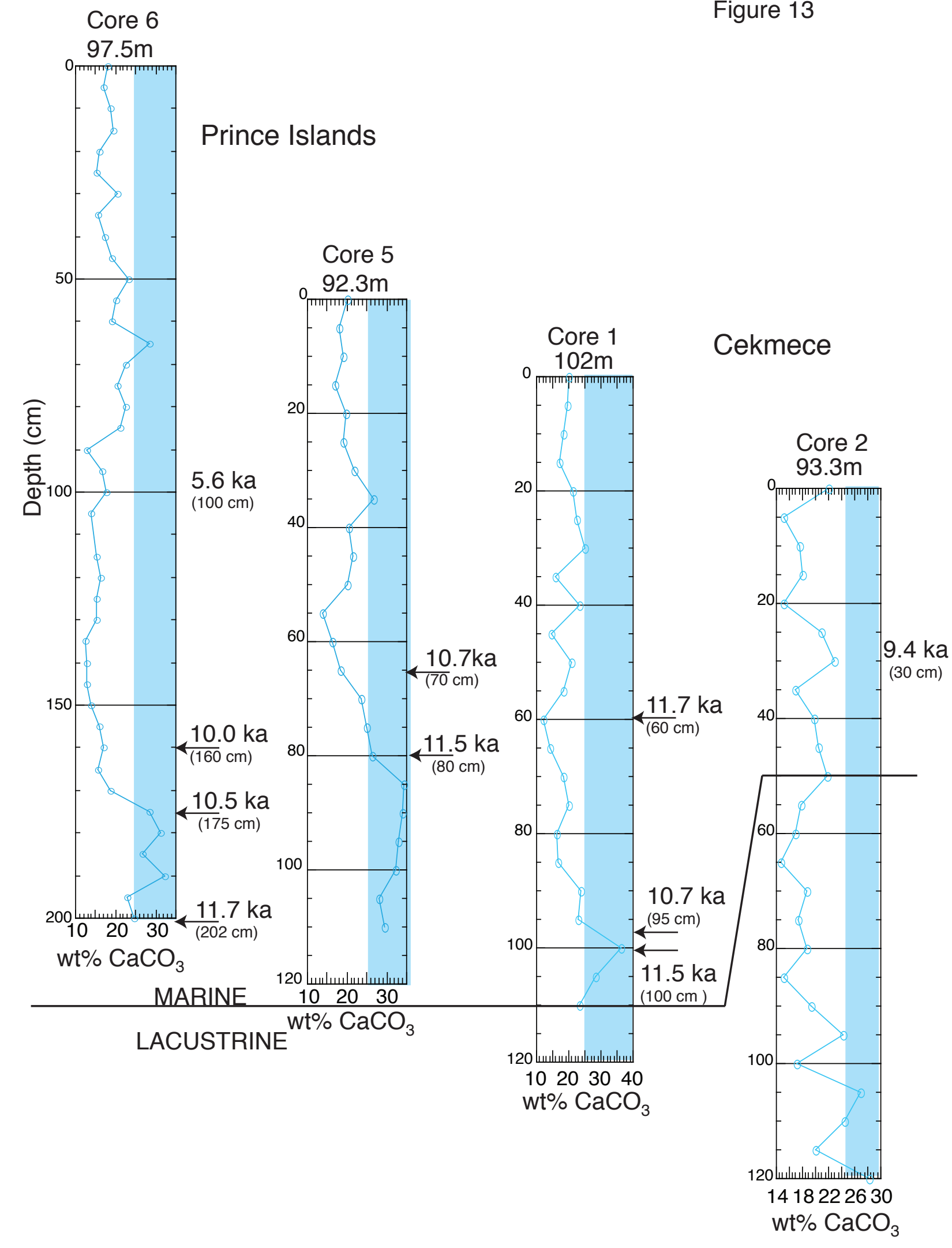

Figure 13 
Figure 14

(a)

(b)
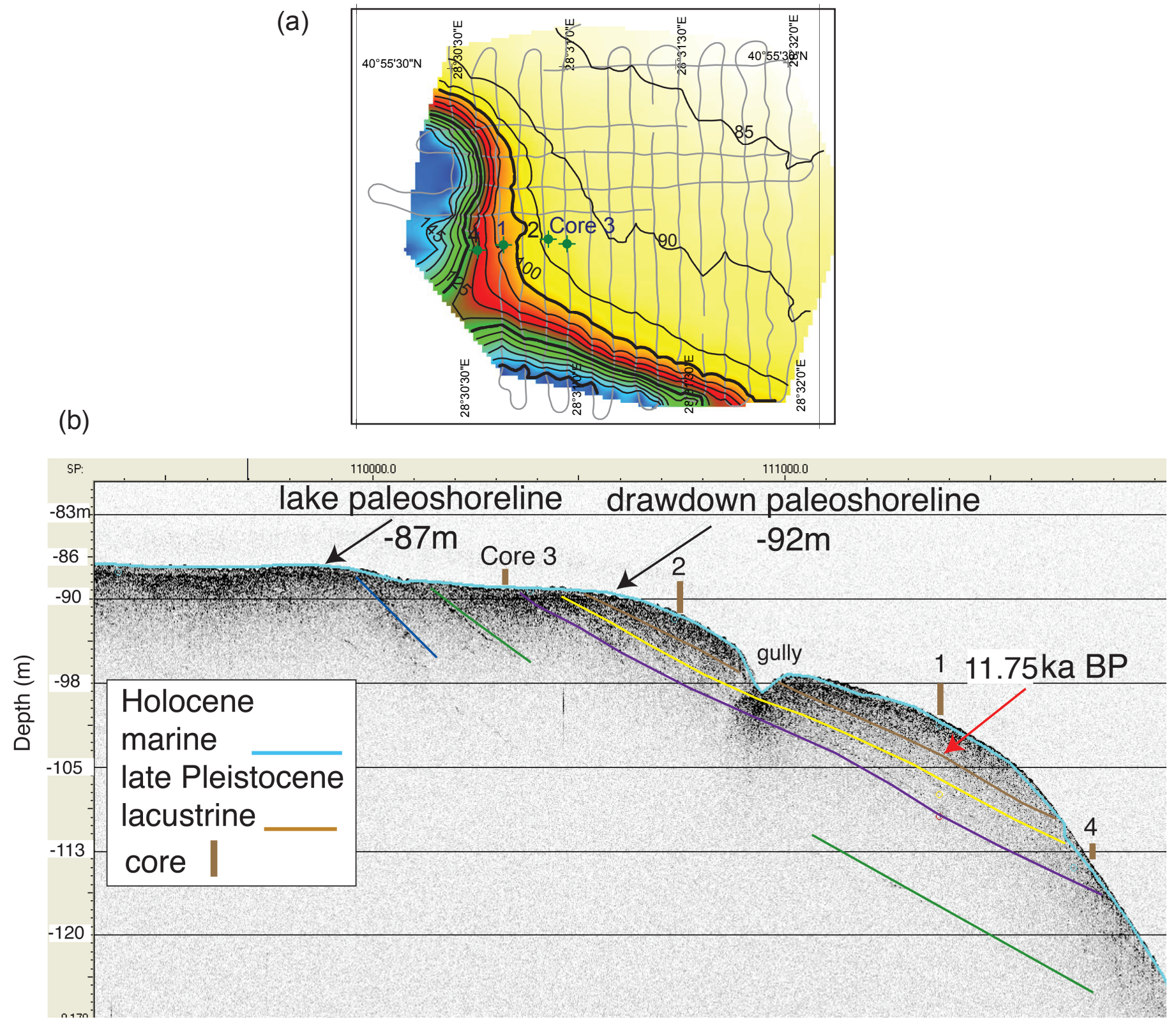
Figure 15

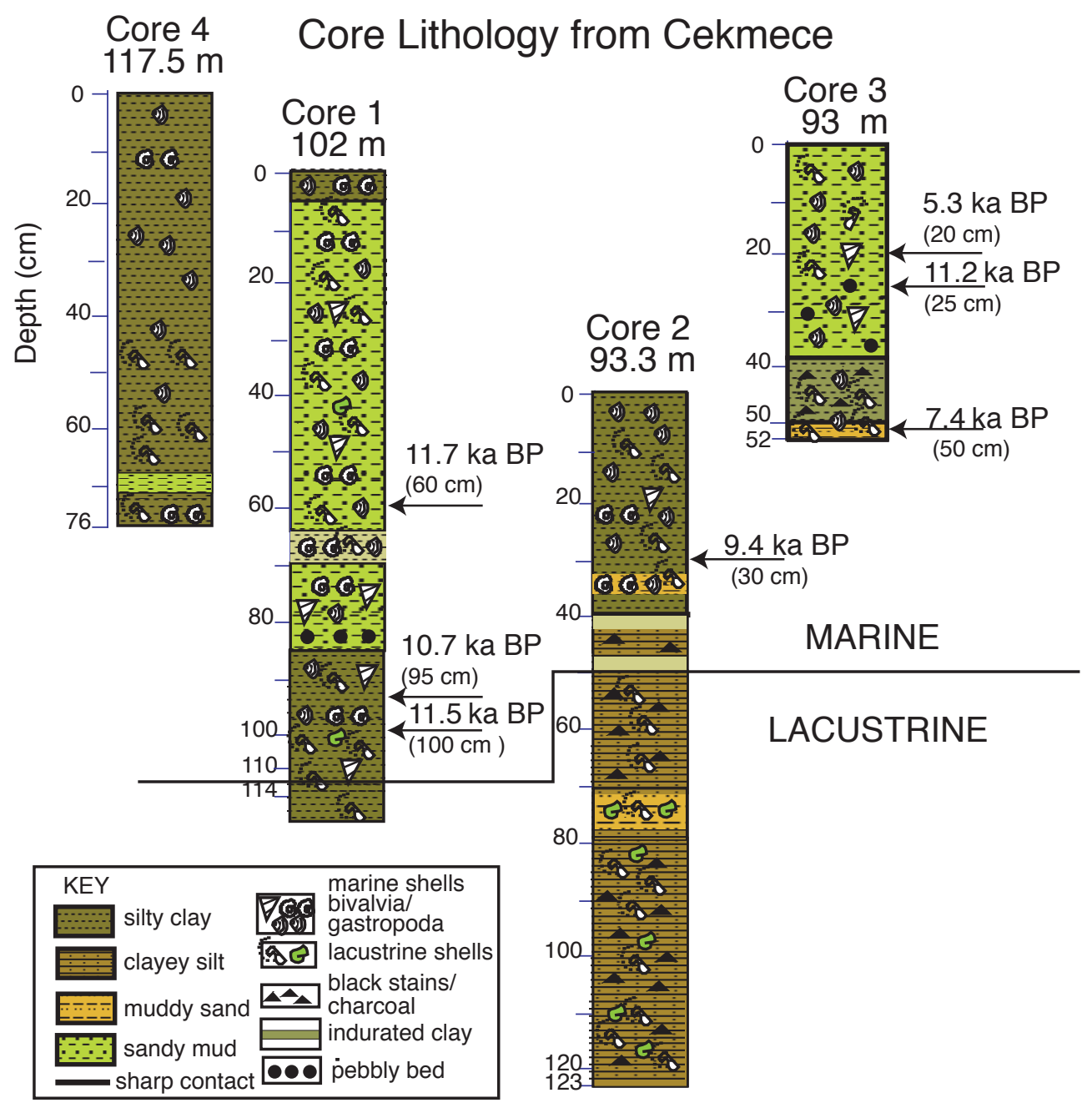




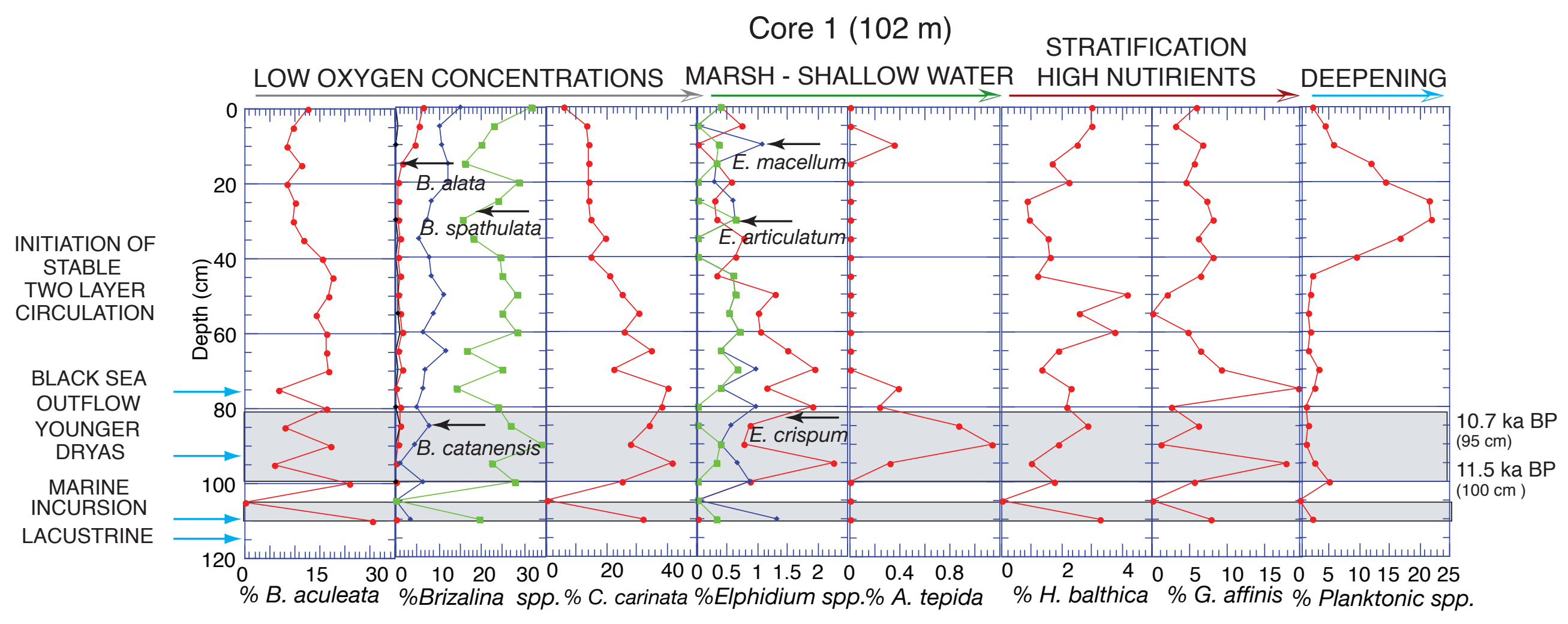




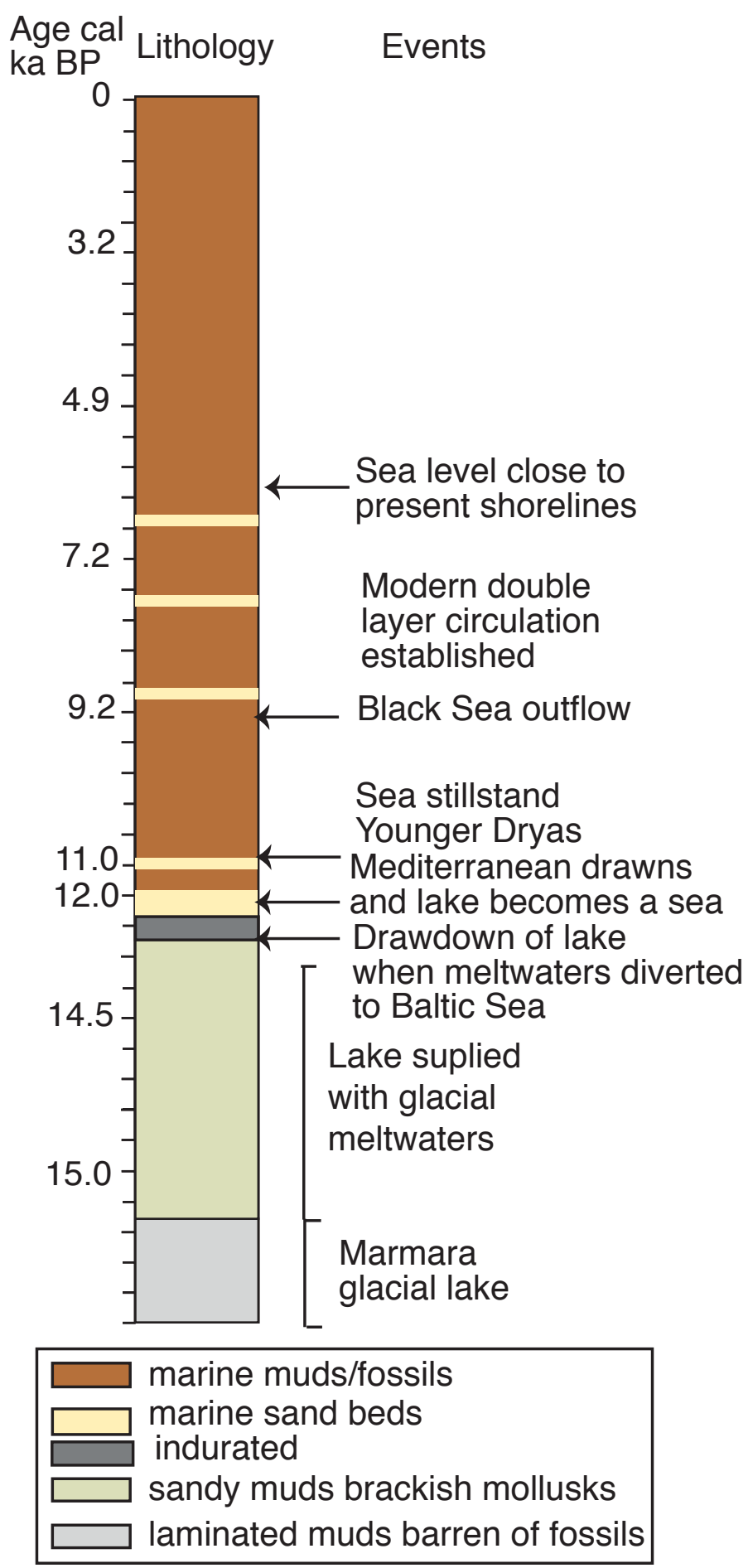

